\title{
Bone substitutes in the Netherlands - a systematic literature review
}

Johan Van der Stok, Esther M.M. Van Lieshout*, Youssef El-Massoudi, Gerdine H. Van Kralingen, Peter Patka

Department of Surgery-Traumatology, Erasmus MC, University Medical Centre Rotterdam, Rotterdam, the Netherlands

* Corresponding author:

Dr. E.M.M. Van Lieshout, PhD

Erasmus MC, University Medical Centre

Department of Surgery-Traumatology

Room H-822k

P.O. Box 2040

3000 CA Rotterdam

The Netherlands

Tel: $+31-10-7031050$

Fax: +31-10-7032396

E-mail: e.vanlieshout@erasmusmc.nl 


\section{Abstract}

BACKGROUND: Autologous bone grafting is currently considered as the gold standard to restore bone defects. However, clinical benefit is not guaranteed and there is an associated 8$39 \%$ complication rate. This resulted in the development of alternative (synthetic) bone substitutes. The aim of this systematic literature review was to provide a comprehensive overview of literature data of bone substitutes registered in the Netherlands for use in trauma and orthopaedic surgery.

METHODS: Brand names of selected products were used as search terms in three available databases: Embase, PubMed, and Cochrane. Manuscripts written in English, German or Dutch that reported on structural, biological or biomechanical properties of the pure product or on its use in trauma and orthopaedic surgery were included.

RESULTS: The primary search resulted in 475 manuscripts for PubMed, 653 for Embase, and 10 for Cochrane. Of these, 218 met the final inclusion criteria. Of each product, structural, biological and biomechanical characteristics as well as their clinical indications in trauma and orthopaedic surgery are provided. All included products possess osteoconductive properties but differ in resorption time and biomechanical properties. They have been used for a wide range of clinical applications; however the overall level of clinical evidence is low.

CONCLUSION: The requirements of an optimal bone substitute are related to size and location of the defect. Calcium phosphate grafts have been used for most trauma and orthopaedic surgery procedures. Calcium sulphates were mainly used to restore bone defects after tumour resection surgery and offer minimal structural support. Bioactive glass remains a potential alternative; however its use has only been studied to a limited extent.

\section{Keywords}

bone substitutes, biomaterials, review, calcium phosphate, calcium sulphate, bioactive glass 


\section{Introduction}

The treatment of fractures remains a continuous challenge for trauma and orthopaedic surgeons. Although most fractures heal uncomplicated, 5-10\% of patients encounter problems due to bone defects, impaired fracture healing, or a combination of both [1]. Significant bone defects or post-traumatic complications such as delayed union, non-union or malunion may require bone-grafting in order to fill the defect. Bone grafts fill voids, provide support, and therefore may enhance the biological repair of the defect. Bone grafting is a common surgical procedure, carried out in approximately $10 \%$ of all skeletal reconstructive surgery cases [2]. Worldwide, an estimated 2.2 million grafting procedures are performed each year [3, 4].

Bone healing differs from any other soft tissue since it heals through the generation of new bone rather than by forming fibrotic tissue. Bone repair requires four critical elements: (1) osteogenic cells (e.g., osteoblasts or progenitor cells); (2) osteoinductive signals provided by growth factors; (3) an osteoconductive matrix; and (4) adequate blood and nutrient supply [5]. Therefore, bone grafts are often described by the terms osteogenicity, osteoinductivity and osteoconductivity. Osteogenicity is the presence of bone forming cells within the bone graft $[6,7]$. Osteoinductivity is the ability of a graft to stimulate or promote bone formation [8]. Osteoconductivity is the ability of the graft to function as a scaffold for ingrowth of new bone and sprouting capillaries [9].

Autologous bone, mostly harvested from the iliac crest, is considered the gold standard since it provides a scaffold for bone ingrowth, contains living bone cells that offer osteogenesis, and contains growth factors that stimulate osteoinduction [6]. However, as the cellular elements do not necessarily survive transplantation, the clinical benefit is not guaranteed [10]. In addition, the harvesting of autologous bone lengthens the surgical procedure, and the graft amount may be insufficient, or the form inappropriate. Moreover, 
autograft harvesting is associated with an 8-39\% risk of complications, e.g., infection, hematoma, nerve and urethral injury, pelvic instability, cosmetic disadvantages, postoperative pain and chronic pain at the donor site [11-14]. Furthermore, autografting is normally not recommended for elderly or paediatric patients or for patients with malignant or infectious disease. Alternative strategies like allo-, and xenotransplantation have major biocompatibility disadvantages compared with autografting $[15,16]$, and as such their use is suboptimal.

Due to complications and limitations associated as reported, alternative bone substitutes were needed. Based upon the above, the perfect bone substitute is osteoconductive, osteoinductive, biocompatible, and bioresorbable. Moreover, it should induce minimal or no fibrotic reaction, undergo remodelling and support new bone formation. From a mechanical point of view bone substitutes should have similar strengths to that of the bone being replaced. Finally, it should be cost-effective and ought to be available in the amount required.

Technological evolution and better understanding of bone-healing biology resulted in the development of numerous alternative bone substitutes. Multiple products, containing (combinations of) hydroxyapatite, tricalcium phosphate, dicalcium phosphate, calcium sulphate (plaster of Paris), or bioactive glass are currently available for use in trauma and orthopaedic surgery. However, an evidence-based guideline to assist surgeons in selecting the best product for specific clinical indications is not available yet. The aim of the current study was to provide a comprehensive overview of literature data of bone substitutes registered in the Netherlands for use in trauma and orthopaedic surgery. An overview of products, their composition, their biological and biomechanical characteristics as well as their clinical indications in trauma and orthopaedic surgery is provided. 


\section{Methods}

\subsection{Product selection}

Products were selected based upon the following criteria: (1) products composed of (combinations of) calcium phosphate, calcium sulphate or bioactive glass; (2) indicated for use in trauma and orthopaedic surgery; and (3) available in the Netherlands on October 12, 2009. Products were excluded if they could only be used in combination with adjunctive (e.g., bone marrow aspirate, growth factors, or antibiotics) or if they were only indicated for use in craniomaxillofacial surgery.

\subsection{Literature search}

Brand names of all products (see Table 1) were used as search terms in three available online databases: Embase, PubMed, and Cochrane. Databases were searched from the earliest date available until July 1, 2010. Titles and abstracts were screened by two researchers (JVDS and YEM). Only papers that reported on structural, biological or biomechanical properties, or on clinical indications in trauma and orthopaedic surgery, and were written in English, German, or Dutch were considered eligible. The full text of all eligible papers retrieved from PubMed and Cochrane were read by two researchers (JVDS and YEM), papers found in Embase were read by three researchers (JVDS, GHVK, and YEM). All references in the selected manuscripts were reviewed in order to ensure that no papers had been missed with the chosen search strategy. For final inclusion a manuscript had to report on structural, biological or biomechanical properties of the pure product or on their use in trauma and orthopaedic surgery. Data regarding study design, species, structural, biological, biomechanical, and clinical findings were collected in a database, and are summarized below. Manuscripts 
reporting on clinical indications of bone substitutes for trauma and orthopaedic surgery were given a level of evidence as described by Mahid et al [17].

\section{Results}

Eighteen bone substitute products were selected. All products were commercially available at July 1, 2010 and the costs per unit range between 100 and 750 Euro. The initial literature search for product name resulted in 475 manuscripts for Pubmed, 653 for Embase and 10 for Cochrane. After screening of all titles and abstracts, 195 manuscripts for Pubmed, 230 for Embase and 1 for Cochrane were considered eligible. Exclusion of 159 duplicates resulted in a total of 267 eligible manuscripts, as shown in Figure 1. After reading the full text of all eligible manuscripts 67 papers had were excluded and 18 were added based upon the reference list. Finally, 218 articles were found to fulfil all inclusion criteria. A detailed overview of the final inclusion per product and subdivision in pre-clinical and clinical studies is given in Table 2.

\subsection{Calcium phosphate}

In the eighties, calcium phosphate salts such as tricalcium phosphate (TCP) and hydroxyapatite (HA) were introduced for clinical use [18]. Multiple calcium phosphate grafts are available with different application forms (eg., pastes, putties, solid matrices, granules). Based upon their chemical composition, calcium phosphates can be separated into hydroxyapatite (HA), tricalcium phosphate (TCP) and composite grafts (Table 1). The latter simply indicating a combination of two or more calcium phosphates. 


\subsubsection{Structural properties}

Structural properties are related to production methods. Therefore a further subdivision can be made between ceramics and cements. A ceramic is defined as an inorganic, non-metallic solid prepared by thermal treatment and subsequent cooling [19], for calcium phosphates ceramics thermal treatment is called sintering. The sintering process removes volatile chemicals and increases crystal size, resulting in a porous and solid material. Cements, first introduced by Brown and Chow [20], consist of a mixture of calcium phosphates which can be applied as a paste and harden in situ due to precipitation reactions.

Hydroxyapatite grafts of ceramic origin are Cerabone ${ }^{\circledR}$, Endobon ${ }^{\circledR}$ and Pro Osteon $500^{\circledR}$. Ostim ${ }^{\circledR}$ is a hydroxyapatite cement. Hydroxyapatite ceramics have a stoichiometry similar to that of bone mineral $[7,21]$. Cerabone ${ }^{\circledR}$ and Endobon ${ }^{\circledR}$ are grafts of bovine origin and Pro Osteon $500^{\circledR}$ is derived from sea coral (genera goniopora). Endobon ${ }^{\circledR}$ has a highly crystalline grain size $(1.57 \pm 0.78 \mu \mathrm{m})$ with an apparent density of $0.35-1.25 \mathrm{~g} / \mathrm{cm}^{3}[22,23]$, and has a porosity of $60-80 \%$ [24], including $18 \%$ micropores and a pore size of $390-1,360 \mu \mathrm{m}$ [22]. Pore sizes of Cerabone ${ }^{\circledR}$ and Pro Osteon $500^{\circledR}$ stated in the product information were $100-1,500 \mu \mathrm{m}$ and $280-770 \mu \mathrm{m}$, respectively. Ostim ${ }^{\circledR}$ is a hydroxyapatite suspension in water, available as a paste.

ChronOS $^{\mathrm{TM}}$ and Vitoss ${ }^{\circledR}$ consist of tricalcium phosphate and are both ceramic materials. Tricalcium phosphate has a stoichiometry similar to that of amorphous bone precursors [21]. ChronOS ${ }^{\mathrm{TM}}$ has a particle size of 1.4-2.8 $\mathrm{mm}$ [25], and has a porosity of 60$75 \%$ [26-28] and a pore size of $100-400 \mu \mathrm{m}[26,28]$.

Included composite grafts of ceramic origin were BoneSave ${ }^{\circledR}$ and Camceram ${ }^{\circledR}$. BoneSave $^{\circledR}$ consists of $80 \%$ TCP and $20 \%$ HA. Camceram ${ }^{\circledR}$ consist of $60 \%$ HA and $40 \% \beta$ TCP. BoneSource ${ }^{\circledR}$, Calcibon $^{\circledR}$, ChronOS $^{\mathrm{TM}}$ Inject, HydroSet ${ }^{\mathrm{TM}}$ and Norian $\mathrm{SRS}^{\circledR}$ are calcium phosphate cements. The setting reaction of calcium phosphate cements leads to the formation 
of either precipitated hydroxyapatite (PHA) or dicalcium phosphate dihydrate (DCPD). Cements have a solid structure characterized by limited porosity and pore size [21]. BoneSource $^{\circledR}$, composed of tetracalcium phosphate and dicalcium phosphate anhydrous, has a porosity of $46 \%[29,30]$ and pore size of $2-50 \mu \mathrm{m}$ [31]. Calcibon ${ }^{\circledR}$ consists of $\alpha$-tricalcium phosphate, and has a porosity of $30-40 \%[32,33]$ with a pore size of $<1 \mu \mathrm{m}$ [33]. Calcibon ${ }^{\circledR}$ has a density of $1.84 \mathrm{~g} / \mathrm{cm}^{3}[32]$ whereas Norian $\mathrm{SRS}^{\circledR}$ has a density of $1.3 \mathrm{~g} / \mathrm{cm}^{3}$ [34].

\subsubsection{Biological properties}

Although highly crystalline TCP and HA derived through thermal treatment do not exist naturally, they have been shown to induce a biologic response similar to that of bone [21]. In general, calcium phosphates are considered to be osteoconductive. However under certain conditions calcium phosphates might also possess osteoinductive properties [35, 36]. Osteoconductive properties were confirmed for most calcium phosphate products (Table 3), however no data were found for BoneSave ${ }^{\circledR}$, Camceram ${ }^{\circledR}$ and HydroSet ${ }^{\mathrm{TM}}$. BoneSource ${ }^{\circledR}$ implanted in an extra skeletal side was able to induce bone formation, and is therefore considered to possess osteoinductive properties [29]. Extra skeletal implantation of Calcibon ${ }^{\circledR}[37]$ and Endobon ${ }^{\circledR}[38]$ did not initiate bone formation.

Biodegradability of HA seems related to its appearance. HA ceramics like Endobon ${ }^{\circledR}$ and Pro Osteon $500^{\circledR}$ are rather inert [39-44], whereas the HA cement Ostim ${ }^{\circledR}$ was shown to be biodegradable by osteoclastic acvitivity [45-50]. After one year, 70\% of the implanted material was resorbed in tibia bone of minipigs [50], but a recently published study only found minimal resorption of Ostim ${ }^{\circledR}$ after an implantation period of 12 weeks in rabbits femora [51]. 
Vitoss ${ }^{\circledR}$ elicits no cytotoxic reaction in in vitro cell cultures [52]. ChronOS $^{\mathrm{TM}}$ and Vitoss ${ }^{\circledR}$ are both resorbed over time $[25,53]$. Resorption of these TCP products is mediated by osteoclastic activity and resorption time varies between 6-24 months [21].

BoneSource $^{\circledR}$ and Calcibon ${ }^{\circledR}$ support cell-growth of osteoblasts in in vitro cell cultures, eliciting no cytotoxic reactions [54-56]. Resorption of composite ceramics is unknown; no data on biodegradation was found for BoneSave ${ }^{\circledR}$ and Camceram ${ }^{\circledR}$. All composite cements were shown to be biodegradable. In vertebral bodies, $20 \%$ of the applied Calcibon ${ }^{\circledR}$ was resolved after one year [57]. ChronOS ${ }^{\mathrm{TM}}$ Inject is almost completely resorbed by osteoclastic activity within six months [58]. Norian $\operatorname{SRS}^{\circledR}$ was biodegraded by osteoclasts [59-62], however one study found no resorption of Norian $\mathrm{SRS}^{\circledR}$ at 12 weeks after implantation in sheep tibia [63].

\subsubsection{Biomechanical properties}

Calcium phosphates generally provide limited biomechanical support, because they are brittle and have little tensile strength [64]. Tricalcium phosphates are less brittle compared with hydroxyapatite; however, their degradation results in subsequent loss of mechanical strength over time. An overview of compression strength, Young's modulus, tensile strength and shear strength of each product is given in Table 4. No data was found for BoneSave ${ }^{\circledR}$, Camceram $^{\circledR}$, ChronOS $^{\mathrm{TM}}$, ChronOS $^{\mathrm{TM}}$ Inject, Ostim $^{\circledR}$, Pro Osteon $500^{\circledR}$, and Vitoss ${ }^{\circledR}$.

Endobon $^{\circledR}$ has an in vitro strength of $1-11 \mathrm{MPa}$ with a Young's modulus of 203,100MPa [22]. In vivo tests showed a 2-20MPa compression strength and a Young's modulus of 20-1,200MPa [24, 65]. Push-out testing of Endobon ${ }^{\circledR}$ after 26 weeks implantation in femoral metaphysair bone of rabbits showed in an interfacial shear stress of 7MPa [24]. Hing et al measured compression strength of Endobon ${ }^{\circledR}$ before (in vitro) and after implantation into rabbit femur condyles for five weeks (in vivo). The in vitro compression 
strength was 2-9MPa and the in vivo compression strength was 6-11MPa, an increase of $195 \%$ [39].

Tricalcium phosphate grafts, ChronOS $^{\mathrm{TM}}$ and Vitoss ${ }^{\circledR}$, were implanted in rabbit tibia and subsequently subjected to torque force. During the study period, torque failure of the grafted tibia increased from $1800 \mathrm{Nm}$ after two weeks to $3400 \mathrm{Nm}$ after 26 weeks, however torque failures at both time point did not differ significantly between ChronOS $^{\mathrm{TM}}$ and Vitoss ${ }^{\circledR}$ [25].

The composite cements BoneSource ${ }^{\circledR}$, Calcibon $^{\circledR}$, HydroSet $^{\mathrm{TM}}$ and Norian SRS ${ }^{\circledR}$ have been tested in various biomechanical experiments. Norian SRS ${ }^{\circledR}$ has an compression strength of $23-55 \mathrm{MPa}[34,66,67]$, with a tensile strength of $2.1 \mathrm{MPa}[66,67]$, and a shear strength of 0.85-1.3MPa [68]. In addition, Norian $\mathrm{SRS}^{\circledR}$ may also be used to augment cortical screws, this results in an increased resistance to torque forces [69]. BoneSource ${ }^{\circledR}$ has a compression strength of $6.3-34 \mathrm{MPa}[70,71]$ with a Young's modulus of $3.6-4.7 \mathrm{MPa}[72,73]$. Interfacial bonding strength of BoneSource ${ }^{\circledR}$ implanted in dog femora was superior to that of the implanted polymethylmethacrylaat (PMMA), which served as a control group [74]. Calcibon ${ }^{\circledR}$ has a compression strength of $35-55 \mathrm{MPa}[32,75]$, with a Young's modulus of 2,5003,000MPa [32] and a tensile strength of 4.5MPa [76]. Of HydroSet ${ }^{\mathrm{TM}}$, compression strength of 14-24MPa and Young's modulus of 125-240MPa [77] and a tensile strengths of 0.110.17MPa were recorded [78].

\subsubsection{Clinical indications}

Each clinical indication requires specific structural, biological and biomechanical properties of graft material. An overview of clinical indications in trauma and orthopaedic surgery of each product is given in Table 5 . 
Hydroxyapatite ceramic Endobon ${ }^{\circledR}$ can be used to fill bone defects of several fracture sites; specifically proximal tibia [43, 79-82], distal tibia [82], distal radius [83, 84] and calcaneus [82]. It provides adequate mechanical stability in open [43, 81, 82] and arthroscopic [80] management of tibia plateau fractures. However, in one case refracture of the proximal tibia occurred seven years after implantation [79]. Huber et al showed treated 24 tibia plateau fractures by using a combination of Ostim ${ }^{\circledR}$ and Cerabone ${ }^{\circledR}$ resulting in an average Rasmussen tibia score of 26 after one year [46]. Ostim ${ }^{\circledR}$ may also be used as sole product for the treatment of fractures of the tibia [85], calcaneus [85], or radius [85-87]. Bone voids resulting of benign bone tumour resections, located in the humerus, tibia, femur, calcaneus, ileum, fibula, and ulna bone were successfully grafted with Pro Osteon $500^{\circledR}$ [88]. Besides, Pro Osteon $500^{\circledR}$ was also used for distal radius fractures [89].

Tricalcium phosphate grafts may be used in the upper and lower extremity. Vitoss ${ }^{\circledR}$ is an option to treat fractures of the tibia or calcaneus, but was also used in the upper extremity, especially in the humerus [90]. ChronOS $^{\mathrm{TM}}$ was used as bone graft in the posterior stabilization and interlaminar fusion of a vertebral fracture type Magerl B2.3 [88].

Of the calcium phosphate cements, Norian SRS ${ }^{\circledR}$ have been tested most extensively. In the upper extremity, union of fractures of the humerus [91] and distal radius [92-100] has been achieved. Norian $\mathrm{SRS}^{\circledR}$ is effective in maintaining realignment of fracture parts after reduction of displaced or comminuted distal radius fractures. This technique resulted in accelerated rehabilitation, and better final outcomes after two years [93, 96, 97]. In the lower extremities, Norian $\mathrm{SRS}^{\circledR}$ can be used to fill metaphyseal bone defects in tibia plateau fractures [101-106]. Good to excellent results at one year after trauma was shown in $95 \%$ of cases [106]. Nonetheless, loss of reduction occurred in 8-20\% of cases and long term results showed a $20 \%$ post-traumatic osteoarthritis rate $[105,106]$. Adding Norian $\mathrm{SRS}^{\circledR}$ to sliding screw fixation for unstable trochanteric fractures resulted in modest improvement of fracture 
healing [107]. Average movement of sliding screw was significantly reduced by augmentation with Norian SRS ${ }^{\circledR}$ after six weeks [108]. In calcaneal fractures this grafting material allows full weight bearing four weeks after surgery compared to eight weeks with autologous augmentation [109]. Another study shows postoperative full weight bearing as early as three weeks shows in standard open reduction with internal fixation in calcaneal fractures [60].

BoneSource ${ }^{\circledR}$ can be used safely when filling of traumatic bone voids is required. Graft sites included the humerus (1), radius (3), femur (1), tibia (9), and calcaneus (7) and reduction was maintained in $83 \%$ [110]. However, BoneSource ${ }^{\circledR}$ alone does not provide adequate fracture stability in distal radius fractures [111]. Calcibon ${ }^{\circledR}$ is used for filling of metaphyseal cancellous bone defects and is was used to stabilize traumatic Magerl type A thoracolumbar fractures [112]. Calcibon ${ }^{\circledR}$ augmentation in vertebral bodies improves pain and function en enables the treated vertebral body to regain height $[113,114]$.

Reports on clinical experience with the use of BoneSave ${ }^{\circledR}$, Camceram $^{\circledR}$, ChronOS $^{\mathrm{TM}}$ Inject and HydroSet ${ }^{\mathrm{TM}}$ without adjunctive in trauma and orthopaedic surgery has not been found.

\subsection{Calcium sulphate}

Calcium sulphates $\left(\mathrm{CaSO}_{4}\right)$ or Plaster of Paris have been used as bone void filler since the late 1800's [115]. Calcium sulphate is produced by heating gypsum, resulting in a dry powder. Adding water to this powder results in an exothermic reaction leading to crystallization and hardening of the preparation. Four calcium sulphate products are available in the Netherlands: Bone Plast $^{\circledR}$, MIIG $^{\circledR}$ X3, OsteoSet ${ }^{\circledR}$, and Stimulan ${ }^{\circledR}$. MIIG ${ }^{\circledR}$ X3 and OsteoSet ${ }^{\circledR}$ are chemically identical; however, $\mathrm{MIIG}^{\circledR} \mathrm{X} 3$ is available in paste, were as OsteoSet ${ }^{\circledR}$ is available in granules or blocks. 


\subsubsection{Structural properties}

No data on structural properties of calcium sulphate grafts has been found.

\subsubsection{Biological properties}

Calcium sulphates appear to function as a resorbable osteoconductive scaffold that provides the structural framework necessary for angiogenesis and osteogenesis while preventing soft tissue invasion by acting as a void filler; however, they lack not only osteogenic but also osteoinductive properties. Calcium sulphate is considered biocompatible, electing little or no macrophagic reaction, and is fully dissolved within 6-12 weeks [116]. MIIG ${ }^{\circledR}$ X3 was found to be osteoconductive [117-119]. The use of OsteoSet ${ }^{\circledR}$ resulted in a $8-35 \%$ new bone ingrowth in animal experiments [116, 120-123] which was found to be equivalent to autogenous and allogenic bone grafts [116]. However, in two studies no osteoconductive potential of OsteoSet ${ }^{\circledR}$ was noted $[124,125]$. No data on osteoconductive properties of Bone Plast ${ }^{\circledR}$ and Stimulan ${ }^{\circledR}$ were found.

\subsubsection{Biomechanical properties}

Compression strength of OsteoSet ${ }^{\circledR}$ and $\mathrm{MIIG}^{\circledR} \mathrm{X} 3$ were attained in similar experiments, using in vivo samples which were implanted in for 26 weeks in the humerus of dogs. Compression strength of OsteoSet ${ }^{\circledR}$ was $0.6-0.9 \mathrm{MPa}[121,123]$ and of $\mathrm{MIIG}^{\circledR} \mathrm{X} 30.6 \mathrm{MPa}$ [123]. Young's modulus of OsteoSet ${ }^{\circledR}$ was $59 \mathrm{MPa}$ [121]. No data on biomechanical properties of Bone Plast ${ }^{\circledR}$ and Stimulan ${ }^{\circledR}$ was found.

\subsubsection{Clinical indications}

Calcium sulphate grafts are mainly used to fill bony voids resulting of tumour resection surgery. Kelly et al used $\mathrm{MIIG}^{\circledR} \mathrm{X} 3$ to graft bone defects of the distal tibia, patella, calcaneus, 
ileum, femur, and humerus [117]. But $\mathrm{MIIG}^{\circledR} \mathrm{X} 3$ may also be used to treat both proximal $[118,123]$ and distal tibia fractures [123] Twenty-one tibia plateau fractures were treated with $\mathrm{MIIG}^{\circledR} \mathrm{X} 3$ and internal fixation, resulting in complete fracture healing and graft resorption after 12 weeks [118].

OsteoSet $^{\circledR}$ fills defects of the humerus, radius, ulna, femur, tibia, fibula and calcaneus [126-130]. However, OsteoSet ${ }^{\circledR}$ may not provide sufficient biomechanical support as several stress fractures after grafting have been reported $[129,131]$ and a self-limiting local sterile inflammatory reaction occurred in 4 to $20 \%$ of graft sites $[129,132,133]$. In one case convulsions as complication with elevated calcium was reported after use of OsteoSet ${ }^{\circledR}$ in a lumbar fracture [134]. Also Bone Plast ${ }^{\circledR}$ may be indicated as it has been used in pelvic, humerus, calcaneus and femoral bone after aspiration of recurrent aneurysmal bone cysts [135]. No data on Stimulan ${ }^{\circledR}$ was found.

\subsection{Bioactive glass}

Bioactive glasses are hard, solid (non-porous), materials consisting of four components: sodium oxide, calcium oxide, silicon dioxide (silicate, the main component) and phosphorous [7]. By varying the proportions of sodium oxide, calcium oxide and silicon dioxide, soluble and non-resorbable grafts can be made [136]. Cortoss ${ }^{\circledR}$ is the only bioactive glass that is available in the Netherlands..

\subsubsection{Structural properties}

Bioactive glasses can be manufactured into microspheres, fibers and porous implants. Cortoss ${ }^{\circledR}$ is available as a paste, but no data concerning other structural properties of Cortoss ${ }^{\circledR}$, such as porosity and pore size,was found. 


\subsubsection{Biological properties}

Bone substitute materials within the group of bioactive glass display osteoinductive and osteoconductive properties [7]. They are bioactive, as they interacts with the body [137]. Bioactivity depends upon the $\mathrm{SiO}_{2}$ content; the bonding between bone and glass is best if the bioactive glass contains $45-52 \% \mathrm{SiO}_{2}$ [137]. The strong graft-bone bonding occurs as a result of the formation of a silicate rich layer after contact with body fluids. On top of this, a layer of hydroxyapatite will form, which directs new bone formation together with protein absorption. The extracellular proteins attract macrophages, mesenchymal stem cells, and osteoprogenitor cells. Subsequently, the osteoprogenitor cells proliferate into matrix-producing osteoblasts $[137,138]$. Cortoss $^{\circledR}$ has osteoconductive properties [139], but is not resorbed [140]. It does not induce cytotoxicity [141], and offers biocompatibility and reduced risk of thermal necrosis [142].

\subsubsection{Biomechanical properties}

Bioactive glass posses superior mechanical strength compared with calcium phosphate products, as a result of a strong graft-bone bonding [7]. Cortoss ${ }^{\circledR}$ has a compression strength of $91-179 \mathrm{MPa}$ with a shear strength of $8.4 \mathrm{MPa}$, which is significantly higher than PMMA bone cements [143, 144]. Manufactures information also provides a Young's modulus of $6,400 \mathrm{MPa}$ and a tensile strength of 52MPa; however this was not confirmed in other studies.

\subsubsection{Clinical indications}

The first reports on clinical applications of bioactive glass emerge in the 1980s [145]. Since then, bioactive glass has been applied for craniofacial reconstructive surgery, dental surgery and trauma or orthopaedic surgery. Reports on clinical applications of Cortoss ${ }^{\circledR}$ are few; no randomized controlled trials have been conducted. Andreassen et al evaluated the use of 
Cortoss $^{\circledR}$ for screw augmentation in 37 Weber type B ankle fractures. After two years, no screw loosening occurred [146]. The use of Cortoss ${ }^{\circledR}$ may relieve pain when used in vertebroplasty $[147,148]$. One case report was published in which successful treatment of an unstable distal radius fracture was described [140].

\section{Discussion}

The repair of large bony defects resulting of trauma or disease remains a major problem in trauma and orthopaedic surgery. Treatment options depend upon size and location of the defect, but patient characteristics like bone quality, age, and co-morbidities also affect outcome. The past decade, an increasing number of bone substitute materials became available for use in trauma and orthopaedic surgery. This systemic literature review was conducted in order to provide a comprehensive overview of characteristics and clinical indications of products available in the Netherlands. Eighteen products, varying in composition and structure, have been reviewed. These products are widely available worldwide, therefore the information provided is relevant for many other countries as well.

Structural, biological and biomechanical properties of bone grafts are critical in their clinical success. Calcium phosphates may possess osteoinductive properties under certain conditions [35, 36]. Of the 18 selected products, osteoinductivity was only found with the use of BoneSource ${ }^{\circledR}$. Overall, osteoconductive properties could be confirmed for almost all included calcium phosphates, calcium sulphates and for bioactive glass. Unfortunately, major differences in experimental design (e.g., animal model) and absence of a standardized scoring system to define quality and quantity of new bone formation troubles the direct comparison among included grafts. 
In order to acquire osteoconductive properties, pore size and porosity, and the degradation potential of the bone substitute material are essential. A macroporous structure of pores ranging $150-500 \mu \mathrm{m}$ in size is considered optimal for ingrowth of new bone $[149,150]$. In addition, interconnective pores increases new bone ingrowth $[149,151,152]$. Microporosity (e.g., pores $<5 \mu \mathrm{m}$ ) is considered important for bioresorbable properties of the material [153]. Resorption rates differ substantially between the products, mainly due to their chemical composition. On average, sintered HA is rather inert, and hardly shows any resorption even after ten years. Tricalcium phosphate and calcium phosphate cement composites, on the other hand, are degraded within approximately two years as a result of osteoclastic activity [21]. Calcium sulphates are generally dissolved within 8-12 weeks [154]. Resorption of bioactive glass is variable, and depends upon the relative amounts of sodium oxide, calcium oxide, silicon dioxide, and phosphorous present [7].

Based upon their structure, hydroxyapatite and tricalcium phosphate ceramics have the advantage of offering a sufficient macroporous structure to facilitate new bone ingrowth. Optimized pore size was confirmed for the products Endobon ${ }^{\circledR}$ and $\operatorname{ChronOS}^{\mathrm{TM}}$ (Table 3). On the other hand, rather quick resorption of calcium sulphate products provides space for new bone formation and prevents the early formation of fibrotic tissue; however, resorption may be completed before sufficient new bone formation. The same accounts for the biodegradable calcium phosphate cements, however their resorption time is slower compared with calcium sulphate products and depends mainly on chemical composition of the graft.

Besides optimal biological properties, bone substitutes should offer direct structural support to surrounding bone and soft tissues. The biomechanical strength is the resultant of a complex interplay between the bone and bone substitute material. In an ideal situation a bone void is grafted by a bone substitute material that offers biomechanical strength similar as the bone being replaced. However, the biomechanical behavior of implanted material may 
undergo changes as a resultant of in vivo interactions, e.g. osteointegration, bone incorporation, or bioresorption of the substitute material. The biomechanical properties of bone itself, on the other hand, differ according to their structure (cortical or cancellous) and function (weight-bearing or non weight-bearing). Grafting a defect with a bone substitute material that has a higher initial biomechanical strength than the surrounding bone may result in stress-shielding and subsequent bone resorption at the bone-implant interface, or may lead to delayed fractures along the bone-implant interface. Using a bone substitute material with a lower biomechanical strength than the surrounding bone may lead to delayed fractures due to the lack of biomechanical stability. As mentioned above, the different products have different resorption rates. Provided that the biodegradation process works as designed, each product may ultimately resorb and remodel back into normal bone. If that holds true, the long-term strength of the restored bone may be similar for different products.

Human cortical bone has a compression strength of 130-290MPa and a tensile strength of 90-190MPa, whereas the compression strength of cancellous bone ranges between 2 and $38 \mathrm{MPa}$ [155]. None of the included bone substitutes offers biomechanical strengths similar to cortical bone, although bioactive glass $\left(\right.$ Cortoss $\left.^{\circledR}\right)$ has a compression strength of 91-197MPa, tensile strength does not reach values comparable to cortical bone [144, 146]. Calcium phosphate grafts possess compression strengths comparable to cancellous bone, but the main drawback of calcium phosphates remains their limited resistance to tensile and shear forces, making it vulnerable to crackling and subsequent material failure. Calcium sulphates only provide minimal structural support and are not suitable in cases were structural support is required (Table 4).

All included bone substitutes are available for use in skeletal surgery in the Netherlands and an overview of clinical indications is given in Table 5. No bone substitute seems to be suitable for grafting of significant cortical bone defects without additive support. 
Calcium phosphate grafts may be used to fill metaphyseal bone defects at various locations of the lower extremity. The use of Norian $\mathrm{SRS}^{\circledR}$ in femur fractures is supported by level II evidence (Table 5). Norian SRS ${ }^{\circledR}$, BoneSource ${ }^{\circledR}$, Endobon ${ }^{\circledR}$ and Ostim ${ }^{\circledR}$ have also been used to fill bony defects of the calcaneus, proximal tibia, distal tibia, or proximal femur, but the clinical evidence remains limited to level IV and consists mainly of level V evidence. In the lower extremity, calcium sulphate is rarely used. Most likely because the minimal structural supportive function. Although bioactive glass offers acceptable biomechanical strength, no evidence was found for their use in the lower extremity. Again in the upper extremity, calcium phosphate grafts are most frequently used. The use of Norian $\mathrm{SRS}^{\circledR}$ in distal radius fractures is supported by level II evidence. In addition, hydroxyapatite ceramics may also be used in open surgical technique to treat distal radius fractures. Furthermore, bioactive glass Cortoss $^{\circledR}$ (Level V) and calcium phosphate Calcibon ${ }^{\circledR}$ (Level II) can be used in vertebral fractures as alternative for PMMA. Calcium sulphate grafts are generally used to fill bone defects after tumour resection surgery, however their minimal biomechanical support may result in secondary fractures.

This data of the current systematic literature review show that vital data concerning structural, biological, biomechanical behavior and also the use of bone substitute for specific clinical indications is limited or incomplete. Additional high-quality scientific evidence is necessary in order to adequately state the clinical benefit of those products as a bone substitute. Evidence regarding their clinical use in trauma and orthopaedic surgery comes mainly from uncontrolled case series (clinical evidence level V). The absence of a control group in this type of research makes it difficult to draw sound conclusion regarding the beneficial effects except the avoidance of auto- or allograft related complications. Three products have been tested in randomized controlled trials (RCTs); Calcibon ${ }^{\circledR}$, BoneSource ${ }^{\circledR}$ and Norian SRS ${ }^{\circledR}$. Although not available for use in the Netherlands, and hence not included 
in this review, a properly designed RCT , and within the literature more well conducted RTCs has also been published on the use of $\alpha$-BSM [156]. This shows that RCTs on efficacy of bone substitutes in trauma and orthopaedic surgery are feasible.

A potential weakness of this study could be the used search strategy which forms the basis of our conclusions. Included products were searched in multiple databases by using product name as search term. By this method we might have missed studies which did not specify the product being used. However, the aim of this systematic review was to provide an overview of available pre-clinical and clinical evidence for the use of bone substitute materials in clinical practice that may guide surgeons for selecting the best product for a particular clinical indication. Therefore manuscripts not specifying the product being used could not be included. The data shown in this manuscript also show that materials consisting of similar chemical compositions do not necessarily possess the same structural, biological and biomechanical properties Differences in production methods (sintered materials versus cements), or in micro- and macrostructure also influences the biological and biomechanical behavior of the material in situ.

This review focuses on the first and vital step to facilitate new bone formation: the creation of an osteoconductive scaffold, as this will be the first clinical step in the treatment of bone defect. In a majority of cases, an osteoconductive scaffold will provide adequate support and will sufficiently facilitate new bone formation by the invasion of nearby bone forming cells. Only in cases where the surrounding bone has insufficient osteoinductive potential, adjunctive growth stimuli such as bone morphogenetic proteins (BMPs) or bone marrow aspirate may be needed in combination with a void filler. The use of growth factors has been reviewed elsewhere $[157,158]$. 


\section{Summary}

The eighteen bone substitute materials available in The Netherlands represent a variety of forms, structure and chemical composition. Some of them have been investigated thoroughly, for other there is limited data available. Determining which material to use for different clinical indications is based on many factors including the size and location of the bone tissue defect as well as structural, biological and biomechanical properties of the graft itself. Calcium phosphate grafts have been used for most trauma and orthopaedic surgery procedures when a grafting is necessary to restore bone defects. Calcium sulphates were mainly used to restore bone defects after tumour resection surgery and do not offer sufficient structural support to be used even in minimal weight baring bones. Bioactive glass remains an interesting alternative; however its use in trauma and orthopaedic surgery is only reported in a limited number of studies. To further improve decision making of bone substitute grafts to treat bony defects, more standardized research to explore the full potential of calcium phosphate, calcium sulphate and bioactive glass is recommended.

\section{Acknowledgements}

Fonds NutsOhra and Biomet Netherlands B.V. are acknowledged for financial support. 


\section{References}

1 Einhorn, T. A. (1995) Enhancement of fracture-healing. J Bone Joint Surg Am 77, 940-956

2 Schnettler, R. and E., M. (1997) Knochenersatzmaterialen und Wachstumsfaktoren. Thieme, Stuttgart

3 Lewandrowski, K. U., Gresser, J. D., Wise, D. L. and Trantol, D. J. (2000) Bioresorbable bone graft substitutes of different osteoconductivities: a histologic evaluation of osteointegration of poly(propylene glycol-co-fumaric acid)-based cement implants in rats. Biomaterials 21, 757-764

4 Muschler, G. F., Negami, S., Hyodo, A., Gaisser, D., Easley, K. and Kambic, H. (1996) Evaluation of collagen ceramic composite graft materials in a spinal fusion model. Clin Orthop Relat Res, 250-260

5 Hing, K. A. (2004) Bone repair in the twenty-first century: biology, chemistry or engineering? Philos Transact A Math Phys Eng Sci 362, 2821-2850

6 Cypher, T. J. and Grossman, J. P. (1996) Biological principles of bone graft healing. J Foot Ankle Surg 35, 413-417

7 Giannoudis, P. V., Dinopoulos, H. and Tsiridis, E. (2005) Bone substitutes: an update. Injury 36 Suppl 3, S20-27

8 Urist, M. R. (1965) Bone: formation by autoinduction. Science 150, 893-899

9 Burchardt, H. (1983) The biology of bone graft repair. Clin Orthop Relat Res, 28-42

10 Sandhu, H. S., Grewal, H. S. and Parvataneni, H. (1999) Bone grafting for spinal fusion. Orthop Clin North Am 30, 685-698

11 Banwart, J. C., Asher, M. A. and Hassanein, R. S. (1995) Iliac crest bone graft harvest donor site morbidity. A statistical evaluation. Spine (Phila Pa 1976) 20, 1055-1060

12 Costantino, P. D. and Friedman, C. D. (1994) Synthetic bone graft substitutes. Otolaryngol Clin North Am 27, 1037-1074

13 Patka, P., Haarman, H. J. and Bakker, F. C. (1998) [Bone transplantation and bone replacement materials]. Ned Tijdschr Geneeskd 142, 893-896

14 Younger, E. M. and Chapman, M. W. (1989) Morbidity at bone graft donor sites. J Orthop Trauma 3, 192-195

15 Asselmeier, M. A., Caspari, R. B. and Bottenfield, S. (1993) A review of allograft processing and sterilization techniques and their role in transmission of the human immunodeficiency virus. Am J Sports Med 21, 170-175

16 Stevenson, S. and Horowitz, M. (1992) The response to bone allografts. J Bone Joint Surg Am 74, 939-950

17 Mahid, S. S., Hornung, C. A., Minor, K. S., Turina, M. and Galandiuk, S. (2006) Systematic reviews and meta-analysis for the surgeon scientist. Br J Surg 93, 13151324

18 Patka, P. (1984) Bone replacement by calcium phosphate ceramics. Vrije Universiteit, Amsterdam

19 Dorozhkin, S. V. (2010) Bioceramics of calcium orthophosphates. Biomaterials 31, 1465-1485

20 Brown, W. E. and Chow, L. C. (1985) Dental restorative cement pastes. US Patent no. 4518430

21 Bohner, M. (2001) Physical and chemical aspects of calcium phosphates used in spinal surgery. Eur Spine J 10 Suppl 2, S114-121

22 Hing, K. A., Best, S. M. and Bonfield, W. (1999) Characterization of porous hydroxyapatite. J Mater Sci Mater Med 10, 135-145 
23 Tadic, D. and Epple, M. (2004) A thorough physicochemical characterisation of 14 calcium phosphate-based bone substitution materials in comparison to natural bone. Biomaterials 25, 987-994

24 Hing, K. A., Best, S. M., Tanner, K. E., Bonfield, W. and Revell, P. A. (2004) Mediation of bone ingrowth in porous hydroxyapatite bone graft substitutes. J Biomed Mater Res A 68, 187-200

25 Walsh, W. R., Vizesi, F., Michael, D., Auld, J., Langdown, A., Oliver, R., Yu, Y., Irie, H. and Bruce, W. (2008) Beta-TCP bone graft substitutes in a bilateral rabbit tibial defect model. Biomaterials 29, 266-271

26 Zeman, P., Zeman, J., Matejka, J. and Koudela, K. (2008) [Long-term results of calcaneal fracture treatment by open reduction and internal fixation using a calcaneal locking compression plate from an extended lateral approach]. Acta Chir Orthop Traumatol Cech 75, 457-464

27 Knop, C., Sitte, I., Canto, F., Reinhold, M. and Blauth, M. (2006) Successful posterior interlaminar fusion at the thoracic spine by sole use of beta-tricalcium phosphate. Arch Orthop Trauma Surg 126, 204-210

28 Hiu-Yan, Y., Ling, Q., Kwong-Man, L., Ming, Z., Kwok-Sui, L. and Chun-yiu, C. J. (2005) Novel approach for quantification of porosity for biomaterial implants using microcomputed tomography (microCT). J Biomed Mater Res B Appl Biomater 75, 234-242

29 Gosain, A. K., Song, L., Riordan, P., Amarante, M. T., Nagy, P. G., Wilson, C. R., Toth, J. M. and Ricci, J. L. (2002) A 1-year study of osteoinduction in hydroxyapatitederived biomaterials in an adult sheep model: part I. Plast Reconstr Surg 109, 619-630

30 Gosain, A. K., Riordan, P. A., Song, L., Amarante, M. T., Kalantarian, B., Nagy, P. G., Wilson, C. R., Toth, J. M. and McIntyre, B. L. (2005) A 1-year study of hydroxyapatite-derived biomaterials in an adult sheep model: III. Comparison with autogenous bone graft for facial augmentation. Plast Reconstr Surg 116, 1044-1052

31 Itthichaisri, C., Wiedmann-Al-Ahmad, M., Huebner, U., Al-Ahmad, A., Schoen, R., Schmelzeisen, R. and Gellrich, N. C. (2007) Comparative in vitro study of the proliferation and growth of human osteoblast-like cells on various biomaterials. J Biomed Mater Res A 82, 777-787

32 Habraken, W. J., Wolke, J. G., Mikos, A. G. and Jansen, J. A. (2006) Injectable PLGA microsphere/calcium phosphate cements: physical properties and degradation characteristics. J Biomater Sci Polym Ed 17, 1057-1074

33 Link, D. P., van den Dolder, J., Wolke, J. G. and Jansen, J. A. (2007) The cytocompatibility and early osteogenic characteristics of an injectable calcium phosphate cement. Tissue Eng 13, 493-500

34 Constantz, B. R., Ison, I. C., Fulmer, M. T., Poser, R. D., Smith, S. T., VanWagoner, M., Ross, J., Goldstein, S. A., Jupiter, J. B. and Rosenthal, D. I. (1995) Skeletal repair by in situ formation of the mineral phase of bone. Science 267, 1796-1799

35 Klein, C., de Groot, K., Chen, W., Li, Y. and Zhang, X. (1994) Osseous substance formation induced in porous calcium phosphate ceramics in soft tissues. Biomaterials $15,31-34$

36 LeGeros, R. Z. (2002) Properties of osteoconductive biomaterials: calcium phosphates. Clin Orthop Relat Res, 81-98

37 Ruhe, P. Q., Hedberg, E. L., Padron, N. T., Spauwen, P. H., Jansen, J. A. and Mikos, A. G. (2005) Biocompatibility and degradation of poly(DL-lactic-co-glycolic acid)/calcium phosphate cement composites. J Biomed Mater Res A 74, 533-544

38 Wiltfang, J., Merten, H. A. and Wiltfang, J. (1996) Ectopic bone formation with the help of growth factor bFGF. J Craniomaxillofac Surg 24, 300-304 
39 Hing, K. A., Best, S. M., Tanner, K. E., Bonfield, W. and Revell, P. A. (1999)

Quantification of bone ingrowth within bone-derived porous hydroxyapatite implants of varying density. J Mater Sci Mater Med 10, 663-670

40 Jensen, S. S., Aaboe, M., Pinholt, E. M., Hjorting-Hansen, E., Melsen, F. and Ruyter, I. E. (1996) Tissue reaction and material characteristics of four bone substitutes. Int J Oral Maxillofac Implants 11, 55-66

41 Liebendorfer, A. and Troster, S. (1997) [Hydroxyapatite ceramics in clinical application. Histological findings in 23 patients]. Unfallchirurgie 23, 60-68

42 Muller-Mai, C., Voigt, C., Hering, A., Rahmanzadeh, R. and Gross, U. (2001) [Madreporic hydroxyapatite granulates for filling bone defects]. Unfallchirurg 104, 221-229

43 Briem, D., Linhart, W., Lehmann, W., Meenen, N. M. and Rueger, J. M. (2002) [Long-term outcomes after using porous hydroxyapatite ceramics (Endobon) for surgical management of fractures of the head of the tibia]. Unfallchirurg 105, 128-133

44 Schnettler, R., Knoss, P. D., Heiss, C., Stahl, J. P., Meyer, C., Kilian, O., Wenisch, S. and Alt, V. (2009) Enhancement of bone formation in hydroxyapatite implants by rhBMP-2 coating. J Biomed Mater Res B Appl Biomater 90, 75-81

45 Schnettler, R., Stahl, J. P., Alt, V., Pavlidis, T., Dingeldein, E. and Wenisch, S. (2004) Calcium phosphate-based bone substitutes. Eur J Trauma

46 Huber, F. X., McArthur, N., Hillmeier, J., Kock, H. J., Baier, M., Diwo, M., Berger, I. and Meeder, P. J. (2006) Void filling of tibia compression fracture zones using a novel resorbable nanocrystalline hydroxyapatite paste in combination with a hydroxyapatite ceramic core: first clinical results. Arch Orthop Trauma Surg 126, 533-540

47 Huber, F. X., Berger, I., McArthur, N., Huber, C., Kock, H. P., Hillmeier, J. and Meeder, P. J. (2008) Evaluation of a novel nanocrystalline hydroxyapatite paste and a solid hydroxyapatite ceramic for the treatment of critical size bone defects (CSD) in rabbits. J Mater Sci Mater Med 19, 33-38

48 Spies, C. K., Schnurer, S., Gotterbarm, T. and Breusch, S. (2009) The efficacy of Biobon and Ostim within metaphyseal defects using the Gottinger Minipig. Arch Orthop Trauma Surg 129, 979-988

49 Thorwarth, M., Schultze-Mosgau, S., Kessler, P., Wiltfang, J. and Schlegel, K. A. (2005) Bone regeneration in osseous defects using a resorbable nanoparticular hydroxyapatite. J Oral Maxillofac Surg 63, 1626-1633

50 Spies, C., Schnurer, S., Gotterbarm, T. and Breusch, S. (2008) [Animal study of the bone substitute material Ostim within osseous defects in Gottinger minipigs]. Z Orthop Unfall 146, 64-69

51 Brandt, J., Henning, S., Michler, G., Hein, W., Bernstein, A. and Schulz, M. Nanocrystalline hydroxyapatite for bone repair: an animal study. J Mater Sci Mater Med 21, 283-294

52 Jager, M., Fischer, J., Schultheis, A., Lensing-Hohn, S. and Krauspe, R. (2006) Extensive $\mathrm{H}(+)$ release by bone substitutes affects biocompatibility in vitro testing. $\mathrm{J}$ Biomed Mater Res A 76, 310-322

53 van Hemert, W. L., Willems, K., Anderson, P. G., van Heerwaarden, R. J. and Wymenga, A. B. (2004) Tricalcium phosphate granules or rigid wedge preforms in open wedge high tibial osteotomy: a radiological study with a new evaluation system. Knee 11, 451-456

54 Burstein, F. D., Williams, J. K., Hudgins, R., Boydston, W., Reisner, A., Stevenson, K. and Cohen, S. (2006) Hydroxyapatite cement in craniofacial reconstruction: experience in 150 patients. Plast Reconstr Surg 118, 484-489 
55 Rossa, C., Jr., Marcantonio, E., Jr., Santos, L. A., Boschi, A. O. and Raddi, M. S. (2005) Cytotoxicity of two novel formulations of calcium phosphate cements: a comparative in vitro study. Artif Organs 29, 114-121

56 Oreffo, R. O., Driessens, F. C., Planell, J. A. and Triffitt, J. T. (1998) Effects of novel calcium phosphate cements on human bone marrow fibroblastic cells. Tissue Eng 4, 293-303

57 Maestretti, G., Cremer, C., Otten, P. and Jakob, R. P. (2007) Prospective study of standalone balloon kyphoplasty with calcium phosphate cement augmentation in traumatic fractures. Eur Spine J 16, 601-610

58 Kuemmerle, J. M., Oberle, A., Oechslin, C., Bohner, M., Frei, C., Boecken, I. and von Rechenberg, B. (2005) Assessment of the suitability of a new brushite calcium phosphate cement for cranioplasty - an experimental study in sheep. $\mathbf{J}$ Craniomaxillofac Surg 33, 37-44

59 Herron, S., Thordarson, D. B., Winet, H., Luk, A. and Bao, J. Y. (2003) Ingrowth of bone into absorbable bone cement: an in vivo microscopic evaluation. Am J Orthop $32,581-584$

60 Elsner, A., Jubel, A., Prokop, A., Koebke, J., Rehm, K. E. and Andermahr, J. (2005) Augmentation of intraarticular calcaneal fractures with injectable calcium phosphate cement: densitometry, histology, and functional outcome of 18 patients. J Foot Ankle Surg 44, 390-395

61 Acarturk, O., Lehmicke, M., Aberman, H., Toms, D., Hollinger, J. O. and Fulmer, M. (2008) Bone healing response to an injectable calcium phosphate cement with enhanced radiopacity. J Biomed Mater Res B Appl Biomater 86, 56-62

62 Apelt, D., Theiss, F., El-Warrak, A. O., Zlinszky, K., Bettschart-Wolfisberger, R., Bohner, M., Matter, S., Auer, J. A. and von Rechenberg, B. (2004) In vivo behavior of three different injectable hydraulic calcium phosphate cements. Biomaterials 25, 14391451

63 Gisep, A., Wieling, R., Bohner, M., Matter, S., Schneider, E. and Rahn, B. (2003) Resorption patterns of calcium-phosphate cements in bone. J Biomed Mater Res A 66, 532-540

64 Martin, R. B., Chapman, M. W., Sharkey, N. A., Zissimos, S. L., Bay, B. and Shors, E. C. (1993) Bone ingrowth and mechanical properties of coralline hydroxyapatite 1 yr after implantation. Biomaterials 14, 341-348

65 Hing, K. A., Best, S. M., Tanner, K. E., Bonfield, W. and Revell, P. A. (1997) Biomechanical assessment of bone ingrowth in porous hydroxyapatite. J Mater Sci Mater Med 8, 731-736

66 Morgan, E. F., Yetkinler, D. N., Constantz, B. R. and Dauskardt, R. H. (1997) Mechanical properties of carbonated apatite bone mineral substitute: strength, fracture and fatigue behaviour. J Mater Sci Mater Med 8, 559-570

67 Moore, D. C., Frankenburg, E. P., Goulet, J. A. and Goldstein, S. A. (1997) Hip screw augmentation with an in situ-setting calcium phosphate cement: an in vitro biomechanical analysis. J Orthop Trauma 11, 577-583

68 Kopylov, P., Tagil, M. and Aspenberg, P. (2001) Delayed surgery does not reduce the interface strength between the surface of a bone fracture and a self-curing injectable hydroxyapatite (Norian SRS). Scand J Plast Reconstr Surg Hand Surg 35, 129-133 Eriksson, F., Mattsson, P. and Larsson, S. (2002) The effect of augmentation with resorbable or conventional bone cement on the holding strength for femoral neck fracture devices. J Orthop Trauma 16, 302-310 
70 Nitsch, A., Patyk, A., Schwartz, P. and Merten, H. A. (2005) [Influence of different mixing fluids on mechanical and micromorphological in vitro qualities of hydroxyapatite cement]. Mund Kiefer Gesichtschir 9, 89-94

71 Pierce, W. A. and Welch, R. D. (1997) Acute compressive strength of hydroxyapatite cement. Trans Orthopd Res Soc, 1014

72 Welch, R. D., Berry, B. H., Crawford, K., Zhang, H., Zobitz, M., Bronson, D. and Krishnan, S. (2002) Subchondral defects in caprine femora augmented with in situ setting hydroxyapatite cement, polymethylmethacrylate, or autogenous bone graft: biomechanical and histomorphological analysis after two-years. J Orthop Res 20, $464-$ 472

73 Crawford, K., Berrey, B. H., Pierce, W. A. and Welch, R. D. (1998) In vitro strength comparison of hydroxyapatite cement and polymethylmethacrylate in subchondral defects in caprine femora. J Orthop Res 16, 715-719

74 Mao, K., Yang, Y., Li, J., Hao, L., Tang, P., Wang, Z., Wen, N., Du, M., Wang, J. and Wang, Y. (2009) Investigation of the histology and interfacial bonding between carbonated hydroxyapatite cement and bone. Biomed Mater 4, 45003

75 Khairoun, I., Boltong, M. G., Driessens, F. C. and Planell, J. A. (1997) Effect of calcium carbonate on clinical compliance of apatitic calcium phosphate bone cement. J Biomed Mater Res 38, 356-360

76 Knepper-Nicolai, B., Reinstorf, A., Hofinger, I., Flade, K., Wenz, R. and Pompe, W. (2002) Influence of osteocalcin and collagen I on the mechanical and biological properties of Biocement D. Biomol Eng 19, 227-231

77 Clarkin, O. M., Boyd, D., Madigan, S. and Towler, M. R. (2009) Comparison of an experimental bone cement with a commercial control, Hydroset. J Mater Sci Mater Med 20, 1563-1570

78 Clarkin, O., Boyd, D. and Towler, M. R. (2009) Comparison of failure mechanisms for cements used in skeletal luting applications. J Mater Sci Mater Med 20, 1585-1594

79 Linhart, W., Briem, D., Amling, M., Rueger, J. M. and Windolf, J. (2004) [Mechanical failure of porous hydroxyapatite ceramics 7.5 years after implantation in the proximal tibial]. Unfallchirurg 107, 154-157

80 Attmanspacher, W., Dittrich, V., Staiger, M. and Stedtfeld, H. W. (2002) [Arthroscopic management of tibial plateau fractures]. Zentralbl Chir 127, 828-836

81 Khodadadyan-Klostermann, C., Liebig, T., Melcher, I., Raschke, M. and Haas, N. P. (2002) Osseous integration of hydroxyapatite grafts in metaphyseal bone defects of the proximal tibia (CT-study). Acta Chir Orthop Traumatol Cech 69, 16-21

82 Helber, M. U. and Ulrich, C. (2000) [Metaphyseal defect substitute: hydroxylapatite ceramic. Results of a 3 to 4 year follow up]. Unfallchirurg 103, 749-753

83 Werber, K. D., Brauer, R. B., Weiss, W. and Becker, K. (2000) Osseous integration of bovine hydroxyapatite ceramic in metaphyseal bone defects of the distal radius. $\mathrm{J}$ Hand Surg Am 25, 833-841

84 Sailer, R., Lutz, M., Zimmermann, R., Hackl, W., Gabl, M. and Blauth, M. (2003) Minimal invasive treatment of displaced metaphyseal fractures of the distal radius Clinical and radiological results after closed reduction, K-wire fixation and substitution with hydroxyapatit ceramic. Aktuelle Traumatologie

85 Huber, F. X., Belyaev, O., Hillmeier, J., Kock, H. J., Huber, C., Meeder, P. J. and Berger, I. (2006) First histological observations on the incorporation of a novel nanocrystalline hydroxyapatite paste OSTIM in human cancellous bone. BMC Musculoskelet Disord 7, 50 
86 Huber, F. X., Hillmeier, J., Kock, H. J., McArthur, N., Huber, C., Diwo, M., Baier, M. and Meeder, P. J. (2008) [Filling of metaphyseal defects with nanocrystalline hydroxyapatite (Ostim) for fractures of the radius]. Zentralbl Chir 133, 577-581 Huber, F. X., Hillmeier, J., Herzog, L., McArthur, N., Kock, H. J. and Meeder, P. J. (2006) Open reduction and palmar plate-osteosynthesis in combination with a nanocrystalline hydroxyapatite spacer in the treatment of comminuted fractures of the distal radius. J Hand Surg Br 31, 298-303

88 Irwin, R. B., Bernhard, M. and Biddinger, A. (2001) Coralline hydroxyapatite as bone substitute in orthopedic oncology. Am J Orthop 30, 544-550

89 Wolfe, S. W., Pike, L., Slade, J. F., 3rd and Katz, L. D. (1999) Augmentation of distal radius fracture fixation with coralline hydroxyapatite bone graft substitute. J Hand Surg Am 24, 816-827

90 Hinz, P., Wolf, E., Schwesinger, G., Hartelt, E. and Ekkernkamp, A. (2002) A new resorbable bone void filler in trauma: early clinical experience and histologic evaluation. Orthopedics 25, s597-600

91 Robinson, C. M. and Page, R. S. (2003) Severely impacted valgus proximal humeral fractures. Results of operative treatment. J Bone Joint Surg Am 85-A, 1647-1655

92 Kopylov, P., Runnqvist, K., Jonsson, K. and Aspenberg, P. (1999) Norian SRS versus external fixation in redisplaced distal radial fractures. A randomized study in 40 patients. Acta Orthop Scand 70, 1-5

93 Sanchez-Sotelo, J., Munuera, L. and Madero, R. (2000) Treatment of fractures of the distal radius with a remodellable bone cement: a prospective, randomised study using Norian SRS. J Bone Joint Surg Br 82, 856-863

94 Kopylov, P., Aspenberg, P., Yuan, X. and Ryd, L. (2001) Radiostereometric analysis of distal radial fracture displacement during treatment: a randomized study comparing Norian SRS and external fixation in 23 patients. Acta Orthop Scand 72, 57-61

95 Kopylov, P., Adalberth, K., Jonsson, K. and Aspenberg, P. (2002) Norian SRS versus functional treatment in redisplaced distal radial fractures: a randomized study in 20 patients. J Hand Surg Br 27, 538-541

96 Zimmermann, R., Gabl, M., Lutz, M., Angermann, P., Gschwentner, M. and Pechlaner, S. (2003) Injectable calcium phosphate bone cement Norian SRS for the treatment of intra-articular compression fractures of the distal radius in osteoporotic women. Arch Orthop Trauma Surg 123, 22-27

97 Cassidy, C., Jupiter, J. B., Cohen, M., Delli-Santi, M., Fennell, C., Leinberry, C., Husband, J., Ladd, A., Seitz, W. R. and Constanz, B. (2003) Norian SRS cement compared with conventional fixation in distal radial fractures. A randomized study. $\mathrm{J}$ Bone Joint Surg Am 85-A, 2127-2137

98 Kopylov, P., Jonsson, K., Thorngren, K. G. and Aspenberg, P. (1996) Injectable calcium phosphate in the treatment of distal radial fractures. J Hand Surg Br 21, 768771

99 Jupiter, J. B., Winters, S., Sigman, S., Lowe, C., Pappas, C., Ladd, A. L., Van Wagoner, M. and Smith, S. T. (1997) Repair of five distal radius fractures with an investigational cancellous bone cement: a preliminary report. J Orthop Trauma 11, 110-116

100 Tyllianakis, M., Giannikas, D., Panagopoulos, A., Panagiotopoulos, E. and Lambiris, E. (2002) Use of injectable calcium phosphate in the treatment of intra-articular distal radius fractures. Orthopedics 25, 311-315

101 Horstmann, W. G., Verheyen, C. C. and Leemans, R. (2003) An injectable calcium phosphate cement as a bone-graft substitute in the treatment of displaced lateral tibial plateau fractures. Injury 34, 141-144 
102 Simpson, D. and Keating, J. F. (2004) Outcome of tibial plateau fractures managed with calcium phosphate cement. Injury 35, 913-918

103 Jubel, A., Andermahr, J., Mairhofer, J., Prokop, A., Hahn, U. and Rehm, K. E. (2004) [Use of the injectable bone cement Norian SRS for tibial plateau fractures. Results of a prospective 30-month follow-up study]. Orthopade 33, 919-927

104 Engel, T., Lill, H., Korner, J., Verheyden, P. and Josten, C. (2003) [Tibial plateau fracture--biodegradable bonecement-augmentation]. Unfallchirurg 106, 97-101

105 Lobenhoffer, P., Gerich, T., Witte, F. and Tscherne, H. (2002) Use of an injectable calcium phosphate bone cement in the treatment of tibial plateau fractures: a prospective study of twenty-six cases with twenty-month mean follow-up. J Orthop Trauma 16, 143-149

106 Keating, J. F., Hajducka, C. L. and Harper, J. (2003) Minimal internal fixation and calcium-phosphate cement in the treatment of fractures of the tibial plateau. A pilot study. J Bone Joint Surg Br 85, 68-73

107 Mattsson, P., Alberts, A., Dahlberg, G., Sohlman, M., Hyldahl, H. C. and Larsson, S. (2005) Resorbable cement for the augmentation of internally-fixed unstable trochanteric fractures. A prospective, randomised multicentre study. J Bone Joint Surg Br 87, 1203-1209

108 Mattsson, P. and Larsson, S. (2003) Stability of internally fixed femoral neck fractures augmented with resorbable cement. A prospective randomized study using radiostereometry. Scand J Surg 92, 215-219

109 Wee, A. T. and Wong, Y. S. (2009) Percutaneous reduction and injection of Norian bone cement for the treatment of displaced intra-articular calcaneal fractures. Foot Ankle Spec 2, 98-106

110 Dickson, K. F., Friedman, J., Buchholz, J. G. and Flandry, F. D. (2002) The use of BoneSource hydroxyapatite cement for traumatic metaphyseal bone void filling. $\mathrm{J}$ Trauma 53, 1103-1108

111 Jeyam, M., Andrew, J. G., Muir, L. T. and McGovern, A. (2002) Controlled trial of distal radial fractures treated with a resorbable bone mineral substitute. J Hand Surg Br 27, 146-149

112 de Falco, R., Scarano, E., Di Celmo, D., Grasso, U. and Guarnieri, L. (2005) Balloon kyphoplasty in traumatic fractures of the thoracolumbar junction. Preliminary experience in 12 cases. J Neurosurg Sci 49, 147-153

113 Grafe, I. A., Baier, M., Noldge, G., Weiss, C., Da Fonseca, K., Hillmeier, J., Libicher, M., Rudofsky, G., Metzner, C., Nawroth, P., Meeder, P. J. and Kasperk, C. (2008) Calcium-phosphate and polymethylmethacrylate cement in long-term outcome after kyphoplasty of painful osteoporotic vertebral fractures. Spine (Phila Pa 1976) 33, 1284-1290

114 Hillmeier, J., Meeder, P. J., Noldge, G., Kock, H. J., Da Fonseca, K. and Kasperk, H. C. (2004) [Balloon kyphoplasty of vertebral compression fractures with a new calcium phosphate cement]. Orthopade 33, 31-39

115 Dressmann, H. (1892) Ueber Knockenplombierung bei Hohlenforming Defekten des Knochens. Beitr Klin Chir 9, 804-810

116 Peters, C. L., Hines, J. L., Bachus, K. N., Craig, M. A. and Bloebaum, R. D. (2006) Biological effects of calcium sulfate as a bone graft substitute in ovine metaphyseal defects. J Biomed Mater Res A 76, 456-462

117 Kelly, C. M. and Wilkins, R. M. (2004) Treatment of benign bone lesions with an injectable calcium sulfate-based bone graft substitute. Orthopedics 27, s131-135 
118 Yu, B., Han, K., Ma, H., Zhang, C., Su, J., Zhao, J., Li, J., Bai, Y. and Tang, H. (2009) Treatment of tibial plateau fractures with high strength injectable calcium sulphate. Int Orthop 33, 1127-1133

119 Watson, J. T. (2004) The use of an injectable bone graft substitute in tibial metaphyseal fractures. Orthopedics 27, s103-107

120 Fujishiro, T., Bauer, T. W., Kobayashi, N., Kobayashi, H., Sunwoo, M. H., Seim, H. B., 3rd and Turner, A. S. (2007) Histological evaluation of an impacted bone graft substitute composed of a combination of mineralized and demineralized allograft in a sheep vertebral bone defect. J Biomed Mater Res A 82, 538-544

121 Urban, R. M., Turner, T. M., Hall, D. J., Infanger, S., Cheema, N. and Lim, T. H. (2003) Healing of large defects treated with calcium sulfate pellets containing demineralized bone matrix particles. Orthopedics 26, s581-585

122 Clokie, C. M., Moghadam, H., Jackson, M. T. and Sandor, G. K. (2002) Closure of critical sized defects with allogenic and alloplastic bone substitutes. J Craniofac Surg 13, 111-121; discussion 122-113

123 Urban, R. M., Turner, T. M., Hall, D. J., Infanger, S. I., Cheema, N., Lim, T. H., Moseley, J., Carroll, M. and Roark, M. (2004) Effects of altered crystalline structure and increased initial compressive strength of calcium sulfate bone graft substitute pellets on new bone formation. Orthopedics 27, s113-118

124 Kuo, S. M., Lin, L. C., Kang, P. L., Tsai, J. C. and Chang, S. J. (2009) Evaluation of bone growth using artificial bone substitute (osteoset) and platelet gel mixtures: a preliminarily study in dogs. Artif Cells Blood Substit Immobil Biotechnol 37, 78-84

125 Chen, W. C., Ju, C. P., Tien, Y. C. and Lin, J. H. (2009) In vivo testing of nanoparticle-treated TTCP/DCPA-based ceramic surfaces. Acta Biomater 5, 17671774

126 Vigler, M., Weigl, D., Schwarz, M., Ben-Itzhak, I., Salai, M. and Bar-On, E. (2006) Subtrochanteric femoral fractures due to simple bone cysts in children. J Pediatr Orthop B 15, 439-442

127 Gitelis, S. and Brebach, G. T. (2002) The treatment of chronic osteomyelitis with a biodegradable antibiotic-impregnated implant. J Orthop Surg (Hong Kong) 10, 53-60

128 Zhang, D. B., Cheng, Q. and Gu, G. S. (2007) Repair of bone defect caused by bone tumor with OsteoSet: Osteoset absorption and new bone growth characters. Journal of Clinical Rehabilitative Tissue Engineering Research

129 Kelly, C. M., Wilkins, R. M., Gitelis, S., Hartjen, C., Watson, J. T. and Kim, P. T. (2001) The use of a surgical grade calcium sulfate as a bone graft substitute: results of a multicenter trial. Clin Orthop Relat Res, 42-50

130 Mirzayan, R., Panossian, V., Avedian, R., Forrester, D. M. and Menendez, L. R. (2001) The use of calcium sulfate in the treatment of benign bone lesions. A preliminary report. J Bone Joint Surg Am 83-A, 355-358

131 Gitelis, S., Virkus, W., Anderson, D., Piasecki, P. and Yao, T. K. (2004) Functional outcomes of bone graft substitutes for benign bone tumors. Orthopedics 27, s141-144

132 Lee, G. H., Khoury, J. G., Bell, J. E. and Buckwalter, J. A. (2002) Adverse reactions to OsteoSet bone graft substitute, the incidence in a consecutive series. Iowa Orthop J 22, 35-38

133 Robinson, D., Alk, D., Sandbank, J., Farber, R. and Halperin, N. (1999) Inflammatory reactions associated with a calcium sulfate bone substitute. Ann Transplant 4, 91-97

134 Smith, I. (2005) Convulsions and Coma Associated with Iatrogenically Elevated CSF Calcium Levels Post Spinal Surgery: A Case Report. Crit Care Resusc 7, 173-176

135 Clayer, M. (2008) Injectable form of calcium sulphate as treatment of aneurysmal bone cysts. ANZ J Surg 78, 366-370 
136 Ohtsuki, C., Kamitakahara, M. and Miyazaki, T. (2009) Bioactive ceramic-based materials with designed reactivity for bone tissue regeneration. J R Soc Interface 6 Suppl 3, S349-360

137 Valimaki, V. V. and Aro, H. T. (2006) Molecular basis for action of bioactive glasses as bone graft substitute. Scand J Surg 95, 95-102

138 Hench, L. L. and Paschall, H. A. (1973) Direct chemical bond of bioactive glassceramic materials to bone and muscle. J Biomed Mater Res 7, 25-42

139 Erbe, E. M., Clineff, T. D. and Gualtieri, G. (2001) Comparison of a new bisphenol-aglycidyl dimethacrylate-based cortical bone void filler with polymethyl methacrylate. Eur Spine J 10 Suppl 2, S147-152

140 Smit, R. S., van der Velde, D. and Hegeman, J. H. (2008) Augmented pin fixation with Cortoss for an unstable AO-A3 type distal radius fracture in a patient with a manifest osteoporosis. Arch Orthop Trauma Surg 128, 989-993

141 DiCicco, M., Compton, R. and Jansen-Varnum, S. A. (2005) In vitro evaluation of orthopedic composite cytotoxicity: assessing the potential for postsurgical production of hydroxyl radicals. J Biomed Mater Res B Appl Biomater 72, 146-155

142 Evans, S. L., Hunt, C. M. and Ahuja, S. (2002) Bone cement or bone substitute augmentation of pedicle screws improves pullout strength in posterior spinal fixation. J Mater Sci Mater Med 13, 1143-1145

143 Boyd, D., Towler, M. R., Wren, A. and Clarkin, O. M. (2008) Comparison of an experimental bone cement with surgical Simplex P, Spineplex and Cortoss. J Mater Sci Mater Med 19, 1745-1752

144 Gheduzzi, S., Webb, J. J. and Miles, A. W. (2006) Mechanical characterisation of three percutaneous vertebroplasty biomaterials. J Mater Sci Mater Med 17, 421-426

145 Reck, R. (1981) Tissue reactions to glass ceramics in the middle ear. Clin Otolaryngol Allied Sci 6, 63-65

146 Andreassen, G. S., Hoiness, P. R., Skraamm, I., Granlund, O. and Engebretsen, L. (2004) Use of a synthetic bone void filler to augment screws in osteopenic ankle fracture fixation. Arch Orthop Trauma Surg 124, 161-165

147 Middleton, E. T., Rajaraman, C. J., O'Brien, D. P., Doherty, S. M. and Taylor, A. D. (2008) The safety and efficacy of vertebroplasty using Cortoss cement in a newly established vertebroplasty service. Br J Neurosurg 22, 252-256

148 Palussiere, J., Berge, J., Gangi, A., Cotten, A., Pasco, A., Bertagnoli, R., Jaksche, H., Carpeggiani, P. and Deramond, H. (2005) Clinical results of an open prospective study of a bis-GMA composite in percutaneous vertebral augmentation. Eur Spine J 14, 982991

149 Blokhuis, T. J., Termaat, M. F., den Boer, F. C., Patka, P., Bakker, F. C. and Haarman, H. J. (2000) Properties of calcium phosphate ceramics in relation to their in vivo behavior. J Trauma 48, 179-186

150 Daculsi, G. and Passuti, N. (1990) Effect of the macroporosity for osseous substitution of calcium phosphate ceramics. Biomaterials 11, 86-87

151 Hulbert, S. F., Young, F. A., Mathews, R. S., Klawitter, J. J., Talbert, C. D. and Stelling, F. H. (1970) Potential of ceramic materials as permanently implantable skeletal prostheses. J Biomed Mater Res 4, 433-456

152 van Eeden, S. P. and Ripamonti, U. (1994) Bone differentiation in porous hydroxyapatite in baboons is regulated by the geometry of the substratum: implications for reconstructive craniofacial surgery. Plast Reconstr Surg 93, 959-966

153 Driskell, T. D., O'Hara, M. J., Sheets, H. D., Jr., Greene, G. W., Jr., Natiella, J. R. and Armitage, J. (1972) Development of ceramic and ceramic composite devices for maxillofacial applications. J Biomed Mater Res 6, 345-361 
154 Beuerlein, M. J. and McKee, M. D. Calcium sulfates: what is the evidence? J Orthop Trauma 24 Suppl 1, S46-51

155 An, Y. H. and Draughn, R. A. (1999) Mechanical testing of bone and bone-implant interface. CRC Press LLC

156 Russell, T. A. and Leighton, R. K. (2008) Comparison of autogenous bone graft and endothermic calcium phosphate cement for defect augmentation in tibial plateau fractures. A multicenter, prospective, randomized study. J Bone Joint Surg Am 90, 2057-2061

157 Giannoudis, P. V. and Dinopoulos, H. T. BMPs: Options, indications, and effectiveness. J Orthop Trauma 24 Suppl 1, S9-16

158 Termaat, M. F., Den Boer, F. C., Bakker, F. C., Patka, P. and Haarman, H. J. (2005) Bone morphogenetic proteins. Development and clinical efficacy in the treatment of fractures and bone defects. J Bone Joint Surg Am 87, 1367-1378

159 Gierse, H. and Donath, K. (1999) Reactions and complications after the implantation of Endobon including morphological examination of explants. Arch Orthop Trauma Surg 119, 349-355

160 Schnettler, R., Dingeldein, E. and Herr, G. (1998) [Defect reconstruction using demineralized bone matrix. Experimental studies on piglets]. Orthopade 27, 80-88

161 Busenlechner, D., Tangl, S., Mair, B., Fugger, G., Gruber, R., Redl, H. and Watzek, G. (2008) Simultaneous in vivo comparison of bone substitutes in a guided bone regeneration model. Biomaterials 29, 3195-3200

162 Huber, F. X., McArthur, N., Heimann, L., Dingeldein, E., Cavey, H., Palazzi, X., Clermont, G. and Boutrand, J. P. (2009) Evaluation of a novel nanocrystalline hydroxyapatite paste Ostim in comparison to Alpha-BSM - more bone ingrowth inside the implanted material with Ostim compared to Alpha BSM. BMC Musculoskelet Disord 10, 164

163 Leupold, J. A., Barfield, W. R., An, Y. H. and Hartsock, L. A. (2006) A comparison of ProOsteon, DBX, and collagraft in a rabbit model. J Biomed Mater Res B Appl Biomater 79, 292-297

164 Feifel, H. (2000) [Bone regeneration in Pro Osteon 500 alone and in combination with Colloss in the patellar gliding model of the rabbit]. Mund Kiefer Gesichtschir 4 Suppl 2, S527-530

165 Thalgott, J. S., Fritts, K., Giuffre, J. M. and Timlin, M. (1999) Anterior interbody fusion of the cervical spine with coralline hydroxyapatite. Spine (Phila Pa 1976) 24, 1295-1299

166 Steffen, T., Stoll, T., Arvinte, T. and Schenk, R. K. (2001) Porous tricalcium phosphate and transforming growth factor used for anterior spine surgery. Eur Spine $\mathrm{J}$ 10 Suppl 2, S132-140

167 Gaasbeek, R. D., Toonen, H. G., van Heerwaarden, R. J. and Buma, P. (2005) Mechanism of bone incorporation of beta-TCP bone substitute in open wedge tibial osteotomy in patients. Biomaterials 26, 6713-6719

168 van der Pol, U., Mathieu, L., Zeiter, S., Bourban, P. E., Zambelli, P. Y., Pearce, S. G., Boure, L. P. and Pioletti, D. P. Augmentation of bone defect healing using a new biocomposite scaffold: An in vivo study in sheep. Acta Biomater

169 Timmins, N. E., Scherberich, A., Fruh, J. A., Heberer, M., Martin, I. and Jakob, M. (2007) Three-dimensional cell culture and tissue engineering in a T-CUP (tissue culture under perfusion). Tissue Eng 13, 2021-2028

170 Miljkovic, N. D., Cooper, G. M., Hott, S. L., Disalle, B. F., Gawalt, E. S., Smith, D. M., McGowan, K. and Marra, K. G. (2009) Calcium aluminate, RGD-modified 
calcium aluminate, and beta-tricalcium phosphate implants in a calvarial defect. $\mathbf{J}$ Craniofac Surg 20, 1538-1543

171 Turner, T. M., Urban, R. M., Singh, K., Hall, D. J., Renner, S. M., Lim, T. H., Tomlinson, M. J. and An, H. S. (2008) Vertebroplasty comparing injectable calcium phosphate cement compared with polymethylmethacrylate in a unique canine vertebral body large defect model. Spine J 8, 482-487

172 Cavalcanti, S. C., Pereira, C. L., Mazzonetto, R., de Moraes, M. and Moreira, R. W. (2008) Histological and histomorphometric analyses of calcium phosphate cement in rabbit calvaria. J Craniomaxillofac Surg 36, 354-359

173 Gosain, A. K., Riordan, P. A., Song, L., Amarante, M. T., Kalantarian, B., Nagy, P. G., Wilson, C. R., Toth, J. M. and McIntyre, B. L. (2004) A 1-year study of osteoinduction in hydroxyapatite-derived biomaterials in an adult sheep model: part II. Bioengineering implants to optimize bone replacement in reconstruction of cranial defects. Plast Reconstr Surg 114, 1155-1163; discussion 1164-1155

174 Morio, D., Lew, D., Krizan, K. and Keller, J. C. (2002) Short-term bone responses to hydroxyapatite cement. Implant Dent 11, 376-382

175 Verheggen, R. and Merten, H. A. (2001) Correction of skull defects using hydroxyapatite cement (HAC)--evidence derived from animal experiments and clinical experience. Acta Neurochir (Wien) 143, 919-926

176 Rupprecht, S., Merten, H. A., Kessler, P. and Wiltfang, J. (2003) Hydroxyapatite cement (BoneSource) for repair of critical sized calvarian defects--an experimental study. J Craniomaxillofac Surg 31, 149-153

177 Libicher, M., Hillmeier, J., Liegibel, U., Sommer, U., Pyerin, W., Vetter, M., Meinzer, H. P., Grafe, I., Meeder, P., Noldge, G., Nawroth, P. and Kasperk, C. (2006) Osseous integration of calcium phosphate in osteoporotic vertebral fractures after kyphoplasty: initial results from a clinical and experimental pilot study. Osteoporos Int 17, 12081215

178 Ooms, E. M., Wolke, J. G., van de Heuvel, M. T., Jeschke, B. and Jansen, J. A. (2003) Histological evaluation of the bone response to calcium phosphate cement implanted in cortical bone. Biomaterials 24, 989-1000

179 Hempel, U., Reinstorf, A., Poppe, M., Fischer, U., Gelinsky, M., Pompe, W. and Wenzel, K. W. (2004) Proliferation and differentiation of osteoblasts on Biocement D modified with collagen type I and citric acid. J Biomed Mater Res B Appl Biomater $71,130-143$

180 Ooms, E. M., Wolke, J. G., van der Waerden, J. P. and Jansen, J. A. (2002) Trabecular bone response to injectable calcium phosphate $(\mathrm{Ca}-\mathrm{P})$ cement. J Biomed Mater Res 61, 9-18

181 Oberle, A., Theiss, F., Bohner, M., Muller, J., Kastner, S. B., Frei, C., Boecken, I., Zlinszky, K., Wunderlin, S., Auer, J. A. and von Rechenberg, B. (2005) [Investigation about the clinical use of brushite- and hydroxylapatite-cement in sheep]. Schweiz Arch Tierheilkd 147, 482-490

182 Baer, W., Schaller, P. and Carl, H. D. (2002) Spongy hydroxyapatite in hand surgery-a five year follow-up. J Hand Surg Br 27, 101-103

183 Joosten, U., Joist, A., Frebel, T., Walter, M. and Langer, M. (2000) The use of an in situ curing hydroxyapatite cement as an alternative to bone graft following removal of enchondroma of the hand. J Hand Surg Br 25, 288-291

184 Mohanty, S. S., Bhasme, V. K., Garg, H. and Wargantiwar, A. (2007) The haemophilic pseudotumour - surgical treatment by excision and filling the defect with calcium-phosphate cement granules. Haemophilia 13, 217-220 
185 Joeris, A., Ondrus, S., Planka, L., Gal, P. and Slongo, T. ChronOS inject in children with benign bone lesions--does it increase the healing rate? Eur J Pediatr Surg 20, 2428

186 Mattsson, P. and Larsson, S. (2004) Unstable trochanteric fractures augmented with calcium phosphate cement. A prospective randomized study using radiostereometry to measure fracture stability. Scand J Surg 93, 223-228

187 Thordarson, D. B. and Bollinger, M. (2005) SRS cancellous bone cement augmentation of calcaneal fracture fixation. Foot Ankle Int 26, 347-352

188 Csizy, M., Buckley, R. E. and Fennell, C. (2001) Benign calcaneal bone cyst and pathologic fracture--surgical treatment with injectable calcium-phosphate bone cement (Norian): a case report. Foot Ankle Int 22, 507-510 
Table 1: Overview of bone substitutes available for clinical use in the Netherlands

\begin{tabular}{|c|c|c|c|c|c|}
\hline Product name & Company & Origin & Chemical composition & Form & Ceramic/cement* \\
\hline \multicolumn{6}{|l|}{ Calcium phosphate } \\
\hline \multicolumn{6}{|l|}{ Hydroxyapatite } \\
\hline Cerabone $^{B}$ & $\begin{array}{l}\text { Fame Medical } \\
\text { Products BV }\end{array}$ & Bovine & HA & solid & Ceramic \\
\hline Endobon $^{\circledR}$ & Biomet & Bovine & HA & solid & Ceramic \\
\hline Ostim $^{\circledR}$ & Heraeus & Synthetic & $60 \% \mathrm{HA} / 40 \% \mathrm{H}_{2} \mathrm{O}$ & paste & Cement \\
\hline Pro Osteon $500^{\circledR}$ & Biomet & Coral & HA & solid & Ceramic \\
\hline \multicolumn{6}{|c|}{ Tricalcium phosphate } \\
\hline ChronOS $^{\mathrm{TM}}$ & Synthes & Synthetic & $\beta$-TCP & solid & Ceramic \\
\hline Vitoss $^{\circledR}$ & Orthovita & Synthetic & $\beta$-TCP & solid & Ceramic \\
\hline \multicolumn{6}{|l|}{ Composite } \\
\hline BoneSave $^{\circledR}$ & Stryker & Synthetic & $80 \%$ TCP / 20\% HA & solid & Ceramic \\
\hline BoneSource $^{\circledR}$ & Stryker & Synthetic & TTCP / DCP & paste & Cement \\
\hline Calcibon $^{\circledR}$ & Biomet & Synthetic & $62.5 \% \alpha-$ TCP / $26.8 \%$ DCPA / $8.9 \% \mathrm{CaCO}_{3} / 1.8 \% \mathrm{HA}$ & paste & Cement \\
\hline Camceram $^{\circledR}$ & CAM Implants & Synthetic & $60 \% \mathrm{HA} / 40 \% \beta-\mathrm{TCP}$ & solid & Ceramic \\
\hline ChronOS $^{\mathrm{TM}}$ Inject & Synthes & Synthetic & $73 \% \beta-$-TCP / $21 \%$ MCP. $\mathrm{H}_{2} \mathrm{O} / 5 \%$ MHPT & paste & Cement \\
\hline HydroSet $^{\mathrm{TM}}$ & Stryker & Synthetic & TTCP / DCP / TSC & paste & Cement \\
\hline Norian SRS ${ }^{\circledR}$ & Synthes & Synthetic & $\alpha-\mathrm{TCP} / \mathrm{CaCO} 3 / \mathrm{MCP} . \mathrm{H}_{2} \mathrm{O}$ & paste & Cement \\
\hline \multicolumn{6}{|l|}{ Calcium sulphate } \\
\hline BonePlast $^{\circledR}$ & Biomet & Synthetic & $\mathrm{CaSO}_{4}$ & paste & \\
\hline $\mathrm{MIIG}^{\circledR} \mathrm{X} 3$ & $\begin{array}{l}\text { Wright Medical } \\
\text { Technology }\end{array}$ & Synthetic & $\mathrm{CaSO}_{4}$ & paste & \\
\hline OsteoSet $^{\circledR}$ & $\begin{array}{l}\text { Wright Medical } \\
\text { Technology }\end{array}$ & Synthetic & $\mathrm{CaSO}_{4}$ & pellets & \\
\hline Stimulan ${ }^{\circledR}$ & Biocomposites & Synthetic & $\mathrm{CaSO}_{4}$ & pellets/paste & \\
\hline \multicolumn{6}{|l|}{ Bioactive glass } \\
\hline Cortoss $^{\circledR}$ & Orthovita & Synthetic & N.S. & paste & \\
\hline
\end{tabular}

*ceramic is defined as an inorganic, non-metallic solid prepared by thermal treatment and subsequent cooling [19]; cement is defined as a product consisting of a liquid solution which hardens in situ through a chemical reaction.

$\mathrm{CaCO}_{3}$ : calcium carbonate, $\mathrm{CaSO}_{4}$ : calcium sulphate, DCP: dicalcium phosphate, DCPA: dicalcium phosphate anhydrous, $\mathrm{MCP} . \mathrm{H}_{2} \mathrm{O}$ :

monocalcium phosphate monohydrate, MHPT: magnesium hydrogen phosphate trihydrate, $\mathrm{H}_{2} \mathrm{O}$ : water, HA: hydroxyapatite, TCP: tricalcium phosphate, TTCP: tetracalcium phosphate, TSC: trisodium citrate, N.S.: not specified 
Table 2: Number of publications retrieved from the systematic literature review on bone substitutes

\begin{tabular}{|c|c|c|c|c|c|c|c|c|c|c|c|c|c|}
\hline \multirow[t]{2}{*}{ Product name } & \multicolumn{2}{|c|}{ PubMed } & \multicolumn{2}{|c|}{ Embase } & \multicolumn{2}{|c|}{ Cochrane } & \multirow{2}{*}{$\begin{array}{c}\text { Total } \\
\text { eligible }\end{array}$} & \multirow{2}{*}{$\begin{array}{c}\text { Omitted } \\
\text { duplicates }\end{array}$} & \multirow[t]{2}{*}{ Exclusion } & \multirow{2}{*}{$\begin{array}{c}\text { Added } \\
\text { references }\end{array}$} & \multirow{2}{*}{$\begin{array}{c}\text { Final } \\
\text { inclusion }\end{array}$} & \multicolumn{2}{|c|}{ Field of study } \\
\hline & Total & Eligible & Total & Eligible & Total & Eligible & & & & & & Pre-clinical* ${ }^{*}$ & Clinical \\
\hline \multicolumn{14}{|l|}{ Calcium phosphate } \\
\hline \multicolumn{14}{|l|}{ Hydroxyapatite } \\
\hline Cerabone $^{\circledR}$ & 3 & 3 & 9 & 4 & 0 & 0 & 7 & 3 & 1 & 0 & 3 & 2 & 1 \\
\hline Endobon $^{\circledR}$ & 22 & 20 & 62 & 28 & 0 & 0 & 48 & 16 & 4 & 1 & 29 & 19 & 10 \\
\hline Ostim $^{\circledR}$ & 23 & 13 & 51 & 16 & 2 & 0 & 29 & 12 & 2 & 1 & 16 & 12 & 4 \\
\hline Pro Osteon $500^{\circledR}$ & 5 & 5 & 16 & 8 & 0 & 0 & 13 & 3 & 5 & 0 & 5 & 2 & 3 \\
\hline \multicolumn{14}{|c|}{ Tricalcium phosphate } \\
\hline ChronOS $^{\mathrm{TM}}$ & 51 & 4 & 100 & 10 & 0 & 0 & 14 & 2 & 5 & 2 & 9 & 7 & 2 \\
\hline Vitoss ${ }^{\circledR}$ & 19 & 14 & 59 & 19 & 3 & 0 & 33 & 16 & 4 & 1 & 14 & 6 & 8 \\
\hline \multicolumn{14}{|l|}{ Composite } \\
\hline BoneSave $^{\mathrm{TM}}$ & 6 & 6 & 15 & 8 & 0 & 0 & 14 & 5 & 6 & 0 & 3 & 1 & 2 \\
\hline BoneSource ${ }^{\circledR}$ & 206 & 35 & 86 & 17 & 1 & 1 & 53 & 20 & 8 & 2 & 27 & 24 & 3 \\
\hline Calcibon $^{\circledR}$ & 7 & 7 & 45 & 18 & 0 & 0 & 25 & 7 & 8 & 5 & 15 & 9 & 6 \\
\hline Camceram $^{\circledR}$ & 1 & 1 & 1 & 1 & 0 & 0 & 2 & 1 & 1 & 0 & 0 & 0 & 0 \\
\hline ChronOS $^{\mathrm{TM}}$ Inject & 6 & 5 & 12 & 6 & 0 & 0 & 11 & 4 & 1 & 0 & 6 & 5 & 1 \\
\hline HydroSet $^{\mathrm{TM}}$ & 2 & 2 & 3 & 2 & 0 & 0 & 4 & 2 & 0 & 0 & 2 & 2 & 0 \\
\hline Norian SRS $^{\circledR}$ & 55 & 40 & 90 & 45 & 1 & 1 & 86 & 32 & 6 & 3 & 51 & 21 & 30 \\
\hline \multicolumn{14}{|l|}{ Calcium sulphate } \\
\hline Bone Plast ${ }^{\circledR}$ & 0 & 0 & 10 & 1 & 0 & 0 & 1 & 0 & 0 & 0 & 1 & 0 & 1 \\
\hline MIIG X3 ${ }^{\circledR}$ & 5 & 1 & 6 & 2 & 0 & 0 & 3 & 0 & 0 & 1 & 4 & 1 & 3 \\
\hline OsteoSet ${ }^{\circledR}$ & 30 & 21 & 29 & 26 & 3 & 0 & 47 & 19 & 10 & 2 & 20 & 9 & 11 \\
\hline Stimulan $^{\circledR}$ & 4 & 3 & 20 & 4 & 0 & 0 & 7 & 3 & 4 & 0 & 0 & 0 & 0 \\
\hline \multicolumn{14}{|l|}{ Bioactive glass } \\
\hline Cortoss $^{\circledR}$ & 21 & 14 & 40 & 15 & 0 & 0 & 29 & 14 & 2 & 0 & 13 & 7 & 6 \\
\hline
\end{tabular}

Database searches were performed until July 1, 2010 (PubMed, Embase and Cochrane). * Pre-clinical studies including biomechanical studies. 
Table 3: Overview of porosity, pore size and biological properties

\begin{tabular}{|c|c|c|c|c|c|c|}
\hline Product name & $\begin{array}{c}\text { Porosity } \\
(\%)\end{array}$ & $\begin{array}{c}\text { Pore size } \\
(\mu \mathrm{m})\end{array}$ & Osteogenic & Osteoinductive & Osteoconductive & Biodegradable \\
\hline \multicolumn{7}{|c|}{ Calcium phosphate } \\
\hline \multicolumn{7}{|l|}{ Hydroxyapatite } \\
\hline Cerabone $^{\circledR}$ & N.D. & $(100-1,500)$ & N.D. & N.D. & Yes[47] & N.D. \\
\hline Endobon $^{\circledR}$ & $60-80[24]$ & $390-1,360[22]$ & N.D. & No [38] & Yes $[24,38,41,43,44,65,82,83,159,160]$ & $\mathrm{No}[39-44]$ \\
\hline Ostim $^{\circledR}$ & N.D. & N.D. & N.D. & N.D. & Yes $[45-50,85,161,162]$ & Yes $[45-50]$ \\
\hline Pro Osteon $500^{\circledR}$ & N.D. & $(280-770)$ & N.D. & N.D. & Yes $[40,163,164]$ & $\mathrm{No}[165]$ \\
\hline \multicolumn{7}{|c|}{ Tricalcium phosphate } \\
\hline ChronOS $^{\mathrm{TM}}$ & $60-75[25,27,28]$ & $100-400[25,28]$ & N.D. & N.D. & Yes[25, 27, 166-168] & Yes[27, 167, 169] \\
\hline Vitoss $^{\circledR}$ & $(88-92)$ & $(1-1,000)$ & N.D. & N.D. & Yes $[25,170]$ & Yes[25] \\
\hline \multicolumn{7}{|l|}{ Composite } \\
\hline BoneSave $^{\circledR}$ & $(50)$ & $(300-500)$ & N.D. & N.D. & N.D. & N.D. \\
\hline BoneSource $^{\circledR}$ & $46[29,30]$ & $2-50[31]$ & N.D. & Yes [29] & Yes[30, 72, 74, 110, 171-176] & Yes[72, 171, 172, 174, 175] \\
\hline Calcibon $^{\circledR}$ & $30-40[32,33]$ & $<1[33]$ & N.D. & No [37] & Yes $[33,37,57,177,178]$ & Yes $[57,179,180]$ \\
\hline Camceram $^{\circledR}$ & N.D. & N.D. & N.D. & N.D. & N.D. & N.D. \\
\hline ChronOS $^{\mathrm{TM}}$ Inject & N.D. & N.D. & N.D. & N.D. & Yes[58, 62, 181] & Yes $[58,62,181]$ \\
\hline HydroSet $^{\mathrm{TM}}$ & N.D. & N.D. & N.D. & N.D. & N.D. & N.D. \\
\hline Norian SRS $^{\circledR}$ & $(50)$ & N.D. & N.D. & N.D. & Yes[59-63, 95] & Yes[59-62]/No[63] \\
\hline \multicolumn{7}{|l|}{ Calcium sulphate } \\
\hline Bone Plast ${ }^{\circledR}$ & N.D. & N.D. & N.D. & N.D. & N.D. & N.D. \\
\hline $\mathrm{MIIG}^{\circledR} \mathrm{X} 3$ & N.D. & N.D. & N.D. & N.D. & Yes[117-119] & Yes[117-119] \\
\hline OsteoSet $^{\circledR}$ & N.D. & N.D. & N.D. & N.D. & Yes[120-123]/No[124, 125] & Yes[120-125, 128] \\
\hline Stimulan $^{\circledR}$ & N.D. & N.D. & N.D. & N.D. & N.D. & N.D. \\
\hline \multicolumn{7}{|l|}{ Bioactive glass } \\
\hline Cortoss $^{\circledR}$ & (1) & N.D. & N.D. & N.D. & Yes[139] & Yes[140] \\
\hline
\end{tabular}

Data obtained from the suppliers are given between brackets.

N.D.: no data available. 
Table 4: Overview of biomechanical properties

\begin{tabular}{|c|c|c|c|c|}
\hline Product name & $\begin{array}{c}\text { Compression } \\
\text { Strength (MPa) }\end{array}$ & $\begin{array}{c}\text { Young's modulus } \\
\text { (MPa) }\end{array}$ & $\begin{array}{c}\text { Tensile strength } \\
\text { (MPa) }\end{array}$ & $\begin{array}{c}\text { Shear } \\
\text { strength } \\
(\mathrm{MPa})\end{array}$ \\
\hline \multicolumn{5}{|c|}{ Calcium phosphate } \\
\hline \multicolumn{5}{|l|}{ Hydroxyapatite } \\
\hline Cerabone $^{\circledR}$ & $(4.2-5.6)$ & N.D. & N.D. & $(1.2-3.4)$ \\
\hline Endobon $^{\circledR}$ & $1-20[22,24,39,65]$ & $20-3100[22,24,65]$ & N.D. & N.D. \\
\hline Ostim $^{\circledR}$ & N.D. & N.D. & N.D. & N.D. \\
\hline Pro Osteon $500^{\circledR}$ & N.D. & N.D. & N.D. & N.D. \\
\hline \multicolumn{5}{|c|}{ Tricalcium phosphate } \\
\hline ChronOS $^{\mathrm{TM}}$ & N.D. & N.D. & N.D. & N.D. \\
\hline Vitoss ${ }^{\circledR}$ & N.D. & N.D. & N.D. & N.D. \\
\hline \multicolumn{5}{|l|}{ Composite } \\
\hline BoneSave $^{\circledR}$ & N.D. & N.D. & N.D. & N.D. \\
\hline BoneSource $^{\circledR}$ & $6.3-34[70,71]$ & $3.6-4.7[72,73]$ & $(2)$ & N.D. \\
\hline Calcibon $^{\circledR}$ & $35-55[32,75]$ & $2500-3000[32]$ & $4.5[56]$ & N.D. \\
\hline Camceram $^{\circledR}$ & N.D. & N.D. & N.D. & N.D. \\
\hline ChronOS $^{\mathrm{TM}}$ Inject & N.D. & N.D. & N.D. & N.D. \\
\hline HydroSet $^{\mathrm{TM}}$ & 14-24[77] & $125-240[77]$ & $0.11-0.17[78]$ & N.D. \\
\hline Norian SRS ${ }^{\circledR}$ & $23-55[34,66,67]$ & N.D. & $2.1[66,67]$ & $0.85-1.3[68]$ \\
\hline \multicolumn{5}{|l|}{ Calcium sulphate } \\
\hline Bone Plast ${ }^{\circledR}$ & N.D. & N.D. & N.D. & N.D. \\
\hline $\mathrm{MIIG}^{\circledR} \mathrm{X} 3$ & $0.6[123]$ & N.D. & N.D. & N.D. \\
\hline OsteoSet $^{\circledR}$ & $0.6-0.9[121,123]$ & $59[121]$ & N.D. & N.D. \\
\hline Stimulan $^{\circledR}$ & N.D. & N.D. & N.D. & N.D. \\
\hline \multicolumn{5}{|l|}{ Bioactive glass } \\
\hline Cortoss ${ }^{\circledR}$ & $91-179[143,144]$ & $(6400)$ & $(52)$ & $8.4[144]$ \\
\hline
\end{tabular}

Data obtained from the suppliers are given between brackets.

N.D.: no data available. 
Table 5: Overview of applications in trauma and orthopaedic surgery

\begin{tabular}{|c|c|c|c|c|c|c|c|c|}
\hline Product name & Fractures & & & & & & & Other \\
\hline & Femur & $\begin{array}{c}\text { Tibia } \\
\text { plateau }\end{array}$ & $\begin{array}{l}\text { Tibia } \\
\text { distal }\end{array}$ & Calcaneus & Humerus & $\begin{array}{c}\text { Radius } \\
\text { distal }\end{array}$ & Vertebra & Bone tumours \\
\hline \multicolumn{9}{|l|}{ Calcium phosphate } \\
\hline \multicolumn{9}{|l|}{ Hydroxyapatite } \\
\hline Cerabone $^{\circledR}$ & N.D. & V [46] & N.D. & N.D. & N.D. & N.D. & N.D. & $\mathrm{x}$ \\
\hline Endobon $^{\circledR}$ & N.D. & $\mathrm{V}[43,80-82]$ & $\mathrm{V}[82]$ & $\mathrm{V}[82]$ & N.D. & V [82-84] & N.D. & V [182] \\
\hline Ostim $^{\circledR}$ & N.D. & $\mathrm{V}[46,85]$ & $\mathrm{x}$ & $\mathrm{V}[85]$ & N.D. & $\mathrm{V}$ [85-87] & N.D. & \\
\hline Pro Osteon $500^{\circledR}$ & N.D. & N.D. & N.D. & N.D. & N.D. & V [89] & N.D. & $\mathrm{V}[88]$ \\
\hline \multicolumn{9}{|c|}{ Tricalcium phosphate } \\
\hline ChronOS $^{\mathrm{TM}}$ & $\mathrm{x}$ & $\mathrm{x}$ & N.D. & $\mathrm{x}$ & $\mathrm{x}$ & $\mathrm{x}$ & VI [27] & $\mathrm{x}$ \\
\hline Vitoss ${ }^{\circledR}$ & N.D. & $\mathrm{V}[90]$ & $\mathrm{V}[90]$ & $\mathrm{V}[90]$ & $\mathrm{V}[90]$ & N.D. & N.D. & N.D. \\
\hline \multicolumn{9}{|l|}{ Composite } \\
\hline BoneSave $^{\mathrm{TM}}$ & N.D. & N.D. & N.D. & N.D. & N.D. & N.D. & N.D. & N.D. \\
\hline BoneSource $^{\circledR}$ & IV [110] & IV [110] & N.D. & IV [110] & IV [110] & IV $[110,111]$ & N.D. & V [183] \\
\hline Calcibon $^{\circledR}$ & N.D. & $\mathrm{x}$ & N.D. & $\mathrm{x}$ & N.D. & $\mathrm{x}$ & II [57, 112-114, 177] & VI [184] \\
\hline Camceram $^{\circledR}$ & N.D. & N.D. & N.D. & N.D. & N.D. & N.D. & N.D. & N.D. \\
\hline ChronOS $^{\mathrm{TM}}$ Inject & $\mathrm{x}$ & $\mathrm{x}$ & N.D. & $\mathrm{x}$ & $\mathrm{x}$ & $\mathrm{x}$ & N.D. & $\mathrm{V}[185]$ \\
\hline HydroSet $^{\text {TM }}$ & N.D. & N.D. & N.D. & N.D. & N.D. & N.D. & N.D. & N.D. \\
\hline Norian SRS $^{\circledR}$ & II $[107,108,186]$ & $\mathrm{V}[101-106]$ & $\mathrm{x}$ & $\mathrm{V}[60,109,187]$ & $\mathrm{V}[91]$ & II [92-100] & N.D. & V [188] \\
\hline \multicolumn{9}{|l|}{ Calcium sulphate } \\
\hline Bone Plast $^{\circledR}$ & N.D. & N.D. & N.D. & N.D. & N.D. & N.D. & N.D. & $\mathrm{V}[135]$ \\
\hline MIIG X3 ${ }^{\circledR}$ & N.D. & $\mathrm{V}[118,119]$ & V [119] & N.D. & N.D. & N.D. & N.D. & V [117] \\
\hline OsteoSet $^{\circledR}$ & N.D. & $\mathrm{x}$ & N.D. & $\mathrm{x}$ & N.D. & $\mathrm{x}$ & N.D. & $\mathrm{V}[126,128-131]$ \\
\hline Stimulan ${ }^{\circledR}$ & N.D. & N.D. & N.D. & N.D. & N.D. & N.D. & N.D. & $\mathrm{X}$ \\
\hline \multicolumn{9}{|l|}{ Bioactive glass } \\
\hline Cortoss ${ }^{\circledR}$ & N.D. & N.D. & N.D. & N.D. & N.D. & VI [140] & $\mathrm{V}[146,148]$ & N.D. \\
\hline
\end{tabular}

I to VI: The highest clinical level of evidence according to Mahid et al [17] supporting use for specific indication. $\mathrm{x}$ : indicated by manufacturer only. N.D.: no data available. 
Figure 1: Flow diagram of literature selection process

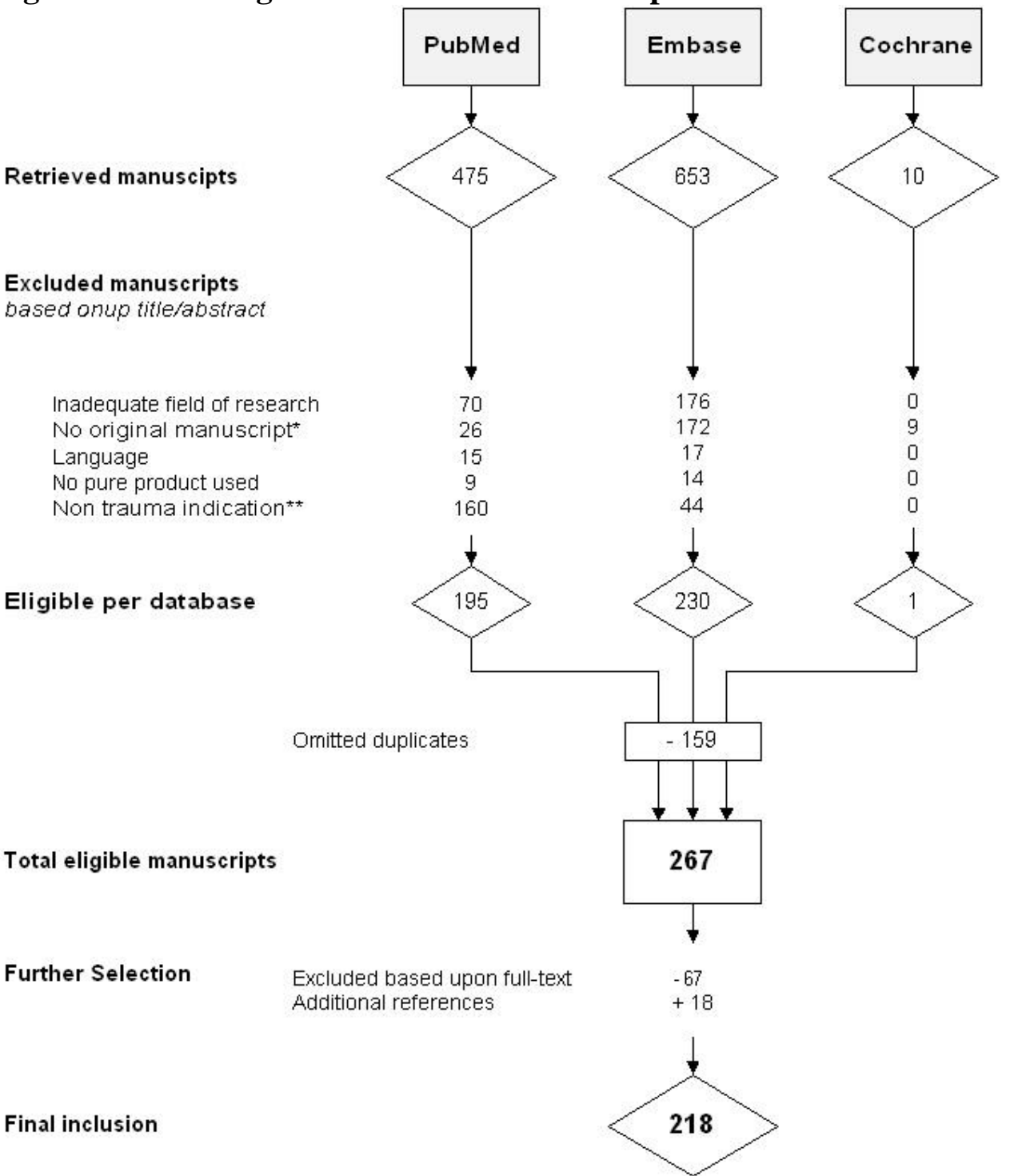

*e.g., reviews, letters, comments, ${ }^{* *}$ e.g., dental or craniomaxillofacial surgery 